\title{
KERAGAAN SISTEM PREMI PENYADAP DI BEBERAPA PERUSAHAAN PERKEBUNAN KARET
}

\author{
Performance of Tapping Premium System in Some Rubber Plantation Enterprises \\ Iif Rahmat FAUZI ${ }^{1)}$, Lina Fatayati SYARIFA ${ }^{2)}$, Eva HERLINAWATI ${ }^{2)}$, \\ dan Nurhawaty SIAGIAN ${ }^{11}$ \\ ${ }^{1}$ Balai Penelitian Sungei Putih, Pusat Penelitian Karet \\ PO BOX 1415 Medan 20001 Sumatera Utara \\ Email : iifrahmatfauzi@gmail.com \\ ${ }^{2}$ Balai Penelitian Sembawa, Pusat Penelitian Karet \\ Jl. Raya Palembang-P. Balai Km.29 PO Box 1127 Palembang 30001 \\ Email : lina_fsy@yahoo.com
}

Diterima : 5 Desember 2013 / Direvisi : 28 Februari 2014 / Disetujui : 30 Mei 2014

\begin{abstract}
Plant productivity in a rubber plantation enterprises are influenced by technical factors of cultivation and nontechnical factors such as tapping management. The main factors of tapping management to support productivity is a premium system. Premium is a reward given by the company to employees or workers who have performed a good job following the rules. This research was conducted in 2012 to find out the performance of premium system in some rubber plantation enterprises. The research used a survey method and interview. Research locations were selected purposively. The results indicated that in general, the type of tapping premiums consisted of regular tapping premiums for achievement, discipline and optimal yield resulted from good tapping, holiday tapping premiums and free tapping premiums. To encourage tapping with optimal yield in quality and quantity, premiums were also given to workers in harvesting activities. Of all types of premiums, important workers deserved premiums were chief foreman, tapping foreman, estate TAP controller, afdeling TAP controller, yield coordinator, afdeling clerk, clerk assistant, yield collectors, and afdeling guard. A foreman and TAP controller had an important contribution in determining tapper class. Their task in several estates were under the control of afdeling. The premium value offoreman and TAP controller was arranged in such a way so that it was equal with the tapper's premium. In such conditions, the implementation of the functions of tapper class in accordance with tapping quality was not representative. In addition to the supervision factor, incentive value set in premium system was considered unable to encourage the tapper to do the tapping norm. It was suggested that special and distinct premium system out of the afdeling structure between tapper class and supervisor should be established.
\end{abstract}

Keywords: Hevea brasiliensis, premiums system, rubber plantation, tapping, supervision.

\section{Abstrak}

Produktivitas tanaman di perusahaan perkebunan karet selain dipengaruhi oleh faktor teknis budidaya juga dipengaruhi oleh faktor nonteknis seperti manajemen penyadapan. Faktor manajemen penyadapan yang paling berpengaruh dalam mendorong produktivitas adalah sistem premi. Premi merupakan suatu penghargaan yang diberikan oleh perusahaan kepada pekerja yang telah melaksanakan tugasnya dengan baik sesuai dengan peraturan yang ditetapkan oleh perusahaan. Penelitian ini bertujuan untuk mengetahui keragaan sistem premi di beberapa perusahaan perkebunan karet. Penelitian dilakukan pada tahun 2012 dengan metode survei dan wawancara. Pemilihan lokasi penelitian dilakukan secara purposive yaitu dengan memilih sentra perkebunan karet terbesar di Indonesia. Hasil penelitian menunjukkan bahwa secara umum jenis premi penyadap di perusahaan perkebunan karet meliputi premi sadap hari biasa (premi prestasi, premi kerajinan, dan premi khusus), premi sadap hari libur, dan premi sadap bebas. Untuk mendukung penyadapan memperoleh hasil yang optimal maka diberikan premi kepada pekerja lain yang berkaitan dengan operasional panen. Di antara jenis premi pekerja lain yang dianggap penting adalah premi mandor besar, mandor sadap, TAP kontrol induk, TAP kontrol afdeling, koordinator produksi, krani afdeling, pembantu krani, pekerja TPH, dan penjaga afdeling. Seorang mandor dan TAP kontrol memiliki kontribusi dalam menentukan kelas penyadap. Perannya pada beberapa kebun berada di bawah kendali afdeling. Nilai premi seorang mandor dan TAP kontrol diatur sedemikian rupa sehingga berbanding lurus dengan nilai premi penyadap. Pada kondisi tersebut penerapan fungsi kelas penyadap yang berkaitan langsung dengan kualitas penyadapan menjadi tidak representatif. Selain faktor peran dari fungsi pengawasan, nilai 
insentif yang diatur dalam sistem premi dinilai belum mampu mendorong penyadap melakukan penyadapan sesuai norma. Diperlukan sistem premi yang tegas terhadap perbedaan kelas penyadap dan peran pengawas yang berdiri sendiri di luar stuktur afdeling sebagaimana yang disampaikan dalam studi ini.

Kata kunci : Hevea brasiliensis, sistem premi, perkebunan karet, penyadapan, pengawas.

\section{PENDAHULUAN}

Produktivitas tinggi dan berkelanjutan dalam satu siklus tanaman karet (20-25 tahun sadap) dengan biaya produksi terkendali merupakan sasaran yang perlu dicapai di dalam agribisnis karet yang berdaya saing tinggi. Kenyataan yang dialami beberapa perusahaan perkebunan saat ini adalah masa sadap yang diharapkan mencapai 20-25 tahun jarang tercapai, kalaupun tercapai produktivitas dalam satu siklus hanya berkisar $12 \mathrm{~s} / \mathrm{d} 23$ ton karet kering $(\mathrm{KK}) / \mathrm{Ha}$ dengan siklus sadap yang semakin menurun yaitu 12-16 tahun. Produktivitas yang tadinya 35-40 ton $\mathrm{KK} / \mathrm{Ha} /$ siklus dapat dikatakan tidak pernah tercapai lagi.

Besar kecilnya produktivitas tanaman di perusahaan perkebunan karet di samping dipengaruhi oleh faktor teknis, juga sangat dipengaruhi faktor non-teknis seperti manusia (penyadap) dan sistem manajemen yang menyertai proses penyadapan itu sendiri. Panjaitan (1997) menyatakan bahwa, kegiatan penyadapan menyerap 35-51\% dari total biaya produksi di tingkat kebun. Sekitar 40\% alokasi tenaga kerja terserap di sektor panen/penyadapan, menyusul kegiatan pemeliharaan tanaman 9-20\%, pengolahan 9-20\%, dan kegiatan sosial $12-29 \%$.

Pada perkebunan karet, selain gaji, faktor manajemen penyadapan yang sangat mendorong produktivitas penyadap adalah sistem premi. Premi yang dimaksud dalam hal ini adalah suatu penghargaan (dalam bentuk uang) yang diberikan oleh perusahaan kepada penyadap yang telah melaksanakan tugasnya dengan baik sesuai dengan peraturan yang ditetapkan oleh perusahaan. Premi sadap secara umum diberikan sebagai upah untuk perolehan sadap di atas basis. Penentuan premi juga didasarkan atas kelas penyadap yang dipengaruhi oleh kriteria kualitas penyadapan, kedisiplinan, serta kebersihan kebun (Nancy, 1997).

Permasalahan yang sering dihadapi di lapangan adalah perusahaan perkebunan karet seringkali memotivasi penyadap untuk memperoleh produksi yang tinggi namun mutu sadapan yang dihasilkan cenderung buruk di mana bidang sadap menjadi rusak dengan pemakaian kulit yang boros. Pemberian premi sadap yang ideal seharusnya bertujuan untuk merangsang penyadap menghasilkan produksi yang optimal sesuai potensi tanaman sekaligus menghasilkan mutu sadapan yang baik. Dengan kata lain, pemberian premi sadap yang ideal dan rasional bertujuan untuk meningkatkan etos kerja penyadap dalam upaya pencapaian produksi yang optimal dan berkelanjutan, serta berpedoman pada norma kerja yang berlaku.

Manfaat bagi perusahaan dengan diterapkannya sistem premi yang tepat adalah : 1) menurunnya biaya sadap per pohon ; 2) kemudahan dalam pengawasan yang meliputi administrasi, mutu hasil sadapan, dan jumlah perolehan hasil serta 3) peningkatan efisiensi perusahaan. Pedoman penentuan premi sadap di beberapa perusahaan perkebunan karet relatif beragam bergantung pada kebijakan manajemen perusahaan masing-masing dalam kaitannya dengan upaya perolehan keuntungan. Penelitian ini bertujuan untuk mengetahui keragaan penetapan dan penerapan sistem premi di beberapa perusahaan perkebunan karet.

\section{BAHAN DAN METODE}

Penelitian dilakukan pada tahun 2012 pada tiga perusahaan perkebunan karet di tiga wilayah/propinsi yang berbeda yaitu: 1) Sumatera Utara, diasumsikan sebagai Perusahaan Perkebunan Karet A, 2) Sumatera Selatan, diasumsikan sebagai Perusahaan Perkebunan Karet B, dan 3) Jawa Tengah, diasumsikan sebagai Perusahaan Perkebunan Karet C. Setiap perusahaan terdiri atas dua kebun yang berbeda. Pemilihan kebun didasarkan pada pertimbangan bahwa di kebun tersebut terdapat blok tanaman yang baru dibuka sadap, tanaman sedang disadap pada panel 
B0-1, tanaman yang sedang disadap pada B0-2, tanaman yang sedang disadap pada BI-1 dan HO (sistem sadap double cut), dan tanaman yang sudah menggunakan sistem sadap bebas. Tujuan pembagian blok tanaman tersebut adalah untuk mengetahui keragaan kualitas sadap dalam hubungannya dengan pemberian premi penyadapan. Untuk mengetahui konsistensi penerapan sistem premi yang diberikan dan mutu sadapan pada setiap kelompok tanaman diambil masing-masing tiga penyadap di salah satu dari tiga perusahaan sampel lokasi penelitian. Pengambilan sampel penyadap ditentukan dengan sengaja, dengan memilih sampel penyadap yang berbeda kelasnya.

Data yang dikumpulkan terdiri atas data primer dan data sekunder. Pengumpulan data primer dilakukan dengan wawancara terhadap pimpinan kebun dan tenaga penyadap. Sementara pengumpulan data sekunder dilakukan dengan teknik pencatatan dan multiplikasi dokumen berupa buku pedoman dan laporan premi sadap perkebunan karet yang diamati. Data yang diperoleh diolah secara tabulasi dan dianalisis secara deskriptif. Variabel primer yang diamati adalah penetapan kriteria kelas penyadap dan kualitas sadapan yang dilihat berdasarkan pengamatan terhadap pemakaian kulit, luka sadapan, kedalaman sadap, kemiringan alur sadap. Penentuan kualitas sadap pada masing-masing perusahaan diterapkan sesuai standar perusahaan masing-masing. Adapun variabel sekunder yang diamati adalah pedoman sistem premi penyadapan di setiap perusahaan perkebunan yang diamati, dasar penentuan basis dan penentuan tarif premi/kg KK oleh manajemen perusahaan, penentuan target produksi oleh perusahaan pada masingmasing blok yang diamati, penerapan TAP kontrol di masing-masing perusahaan, pengamatan dan penilaian terhadap premi mandor, mandor besar, dan TAP kontrol.

\section{HASIL DAN PEMBAHASAN}

\section{Pengertian Basis Tugas, Target Produksi, dan Penerapannya}

Di ketiga perusahaan yang diamati, berlaku secara umum bahwa premi hanya diberikan kepada penyadap yang mampu memperoleh produksi melebihi basis tugas yang ditetapkan oleh perusahaan. Pada tanaman yang baru dibuka sadap, tanaman promosi, dan tanaman tua yang telah menganut sistem sadap bebas tidak diberlakukan lagi basis tugas kepada penyadap. Hal ini sesuai dengan pengertian bahwa basis tugas merupakan beban kerja seorang penyadap yang diukur berdasarkan jumlah produksi karet kering yang harus diperoleh melalui kegiatan penyadapan. Basis tugas adalah jumlah minimal produksi karet kering yang harus dicapai oleh seorang penyadap untuk mendapatkan premi penyadapan. Dengan kata lain jumlah premi penyadap dihitung jika seorang penyadap mampu mendapatkan produksi melebihi basis tugas yang telah ditetapkan.

Pada setiap perusahaan yang diamati, estimasi/target produksi ditetapkan dengan memperhitungkan persentase keuntungan yang hendak dicapai oleh perusahaan, sedangkan basis tugas ditentukan berdasarkan minimal produksi yang harus dicapai untuk menutupi biaya dari harga pokok produksi, sehingga penentuan persentase basis tugas sangat bergantung pada kemampuan perusahaan tersebut dalam mengelola biaya produksi. Terdapat perbedaan dalam penentuan persentase basis tugas yang diberikan kepada penyadap. Pada Perusahaan Perkebunan Karet A dan B, persentase basis tugas ditentukan sebesar $70 \%$ dari target produksi. Sementara pada Perusahaan Perkebunan Karet C, persentase basis tugas ditentukan sebesar $76,5 \%$ dari target produksi.

Basis tugas untuk tiap penyadap ditentukan berdasarkan estimasi/target produksi per tahun tanam dan dihitung per hari sadap. Basis tugas pada bulan yang bersangkutan ditentukan berdasarkan estimasi/target produksi (dinas + borong) bulan berjalan. Adapun persentase (\%) produksi lateks dan lump per penyadap dihitung berdasarkan masing-masing sistem sadap. Pada setiap kebun dan sistem sadap yang digunakan persentase produksi lateks selalu lebih besar dari persentase produksi lump/scrap. Ketentuan ini diberikan berdasarkan pertimbangan bahwa kualitas lateks lebih baik daripada lump/scrap sehingga perolehan keuntungan perusahaan dari penjualan produksi menjadi lebih besar. 
Tabel 1. Persentase produksi lateks dan lump/scrap kering menurut sistem sadap Table 1. Percentage of dry latex and lump/scrap based on tapping system

\begin{tabular}{cccccc}
\hline \multirow{2}{*}{$\begin{array}{c}\text { Uraian } \\
\text { Description }\end{array}$} & $\begin{array}{c}\text { Sistem } \\
\text { sadap } \\
\text { Tapping } \\
\text { system }\end{array}$ & \multicolumn{2}{c}{$\begin{array}{c}\text { Persentase lateks-lump } \\
\text { Percentage of latex-lump } \\
(\%)\end{array}$} & \multicolumn{2}{c}{$\begin{array}{c}\text { Persentase basis tugas } \\
\text { Percentage of task base } \\
(\%)\end{array}$} \\
\cline { 3 - 6 } Kulit perawan & $1 / 2 \mathrm{~S} \mathrm{~d} / 4$ & 90 & $\begin{array}{c}\text { Lump/scrap } \\
\text { Latex }\end{array}$ & $\begin{array}{c}\text { Lateks } \\
\text { Latex }\end{array}$ & $\begin{array}{c}\text { Lump/scrap } \\
\text { Lump/scrap }\end{array}$ \\
\hline \multirow{3}{*}{ Kulit pulihan } & $1 / 2 \mathrm{~S} \mathrm{~d} / 3$ & 85 & 10 & $70 \times 90$ & $70 \times 10$ \\
Sadap ATS & $1 / 2 \mathrm{~S} \mathrm{~d} / 3$ & 85 & 15 & $70 \times 85$ & $70 \times 15$ \\
Sadap berat & $1 / 2 \mathrm{~S} \mathrm{~d} / 4$ & 80 & 20 & $70 \times 80$ & $70 \times 15$ \\
\hline
\end{tabular}

Sumber : Perusahaan B (2010)

Source : Company B (2010)

Tabel 1 memperlihatkan salah satu contoh penentuan persentase basis produksi lateks serta lump/scrap kering menurut sistem sadap di Kebun A dan B.

Sistem premi pada masing-masing perusahaan yang diamati tidak terlepas dari penentuan basis dan target produksi. Penetapan target produksi berkaitan dengan pendapatan perusahaan sementara basis berkaitan dengan biaya perusahaan. Selisih antara target dan basis secara tidak langsung berkaitan dengan perolehan keuntungan perusahaan. Dalam penerapannya baik target maupun basis produksi diturunkan ke dalam satuan bulanan hingga harian dan didistribusikan ke dalam masing-masing satuan tugas per blok per afdeling. Gambar 1 memperlihatkan ruang lingkup penentuan sistem premi penyadapan di perusahaan perkebunan karet.

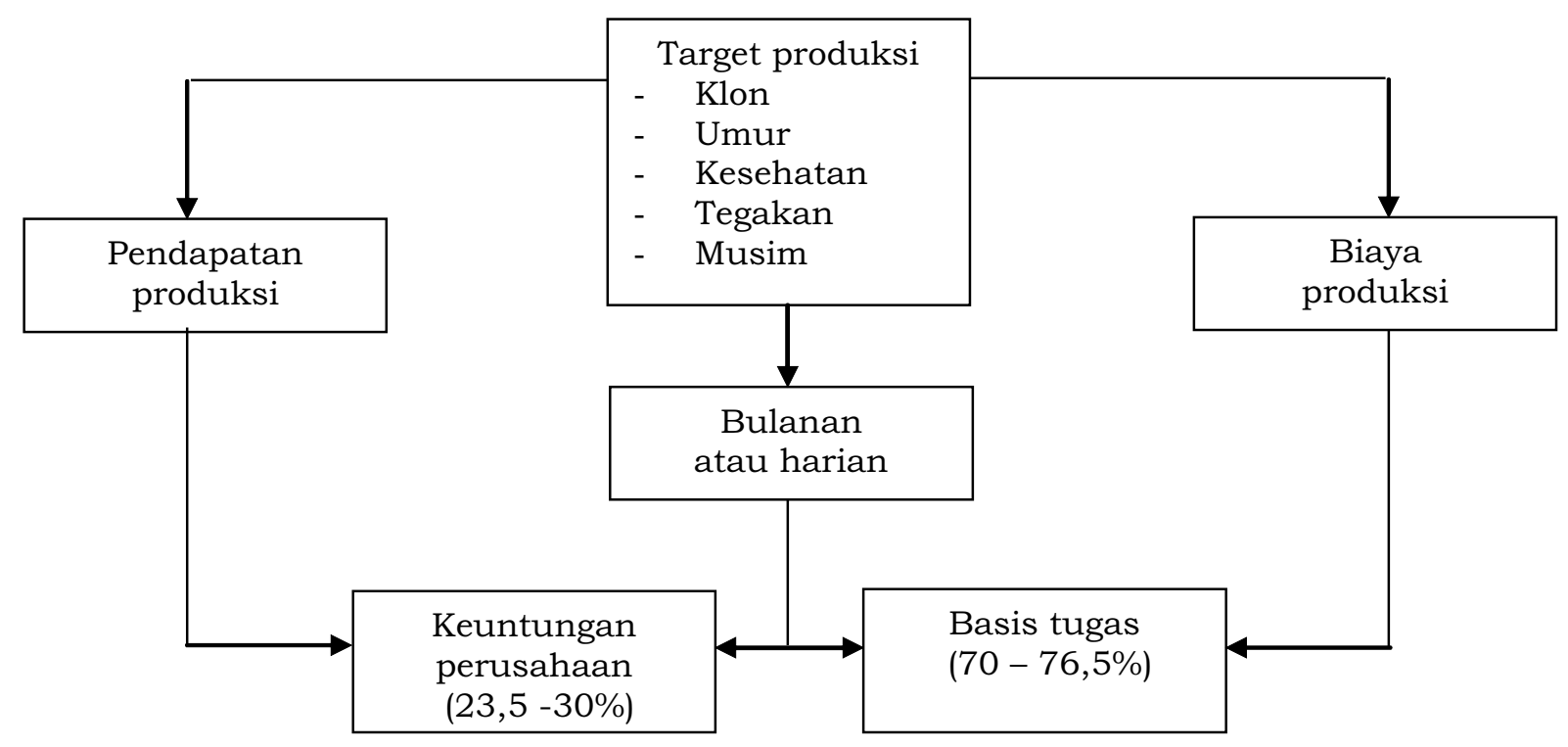

Gambar 1. Ruang lingkup sistem premi penyadapan

Figure 1. Scope of tapping premiums system 
Basis tugas harian yang ditetapkan kepada kebun seringkali tidak tercapai akibat faktor alam berupa turunnya hujan pada saat jam kerja. Di satu sisi kebun dibebankan pada target yang telah ditetapkan, sementara di sisi lain kendala yang tidak dapat dihindari ini secara teknis memberatkan penyadap untuk melakukan penyadapan. Pada Perusahaan Perkebunan A dan B, untuk memotivasi penyadap saat adanya gangguan hujan, penetapan basis tugas diturunkan secara proporsional berdasarkan lamanya waktu hujan. Tabel 2 memperlihatkan ketentuan penyesuaian basis tugas yang dianut oleh Perusahaan A dan B.

Berdasarkan Tabel 2 apabila tejadi hujan yang mengakibatkan jam kerja penyadap berkurang maka basis tugas dihitung secara proporsional berdasarkan jumlah jam kerja efektif penyadap dibagi jam kerja normal dan dikalikan basis normal. Sebagai contoh apabila turun hujan selama 3 jam maka jam kerja efektif adalah 4 jam, sehingga basis penyesuaikan dihitung sebesar 4/7 dikali basis normal. Penyesuaian basis tugas terhadap topografi lahan diterapkan khusus oleh Kebun A dimana pada kategori areal berbukit basis tugas ditetapkan sebesar 90\% dari basis normal, sementara pada kategori areal curam basis tugas ditetapkan sebesar $75 \%$ dari basis normal.

Pada Perusahaan $\mathrm{C}$ basis tugas ditentukan secara kumulatif untuk 1 bulan penyadapan tanpa mempertimbangkan adanya gangguan hujan. Walaupun demikian penerapan basis tugas harian tetap diberlakukan. Apabila basis tugas tersebut tidak tercapai maka penyadap melakukan recovery pada hari berikutnya untuk menutupi kekurangan produksi pada hari dimana produksi tidak tercapai. Metode ini memiliki kelemahan karena hari hujan merupakan faktor alam yang tidak bisa dihindari sehingga target harian seyogyanya dikurangi secara proporsional sebagaimana berlaku pada Kebun A dan B.

Secara umum dari ketiga perusahaan yang diamati diketahui bahwa target produksi yang ditetapkan cenderung berada di atas potensi tanaman. Target yang tinggi tersebut tentu berpengaruh langsung terhadap penentuan basis tugas penyadap. Semakin besar target produksi yang ditetapkan perusahaan maka semakin tinggi basis produksi yang harus dicapai oleh seorang penyadap. Kondisi seperti ini tentunya memberatkan penyadap untuk mencapai basis yang ditentukan sebagai batas minimal perolehan premi. Nominal basis yang terlalu tinggi dianggap cenderung menurunkan semangat penyadap untuk mencapai hasil optimal yang bisa mereka dapatkan dari kegiatan menyadap. Selain itu, nilai target dan basis produksi yang terlalu tinggi dikhawatirkan mendorong penyadap melakukan penyadapan yang tidak sesuai dengan norma, seperti penyadapan yang terlalu dalam dan pemakaian kulit yang boros. Dalam upaya meningkatkan produktivitas estimasi/target produksi seyogianya ditetapkan

Tabel 2. Ketentuan penyesuaian basis produksi harian

Table 2. Adjustment base of daily production

\begin{tabular}{ccc}
\hline $\begin{array}{c}\text { Lama hujan } \\
\text { (jam) } \\
\begin{array}{c}\text { Rainy duration } \\
\text { (hour) }\end{array}\end{array}$ & $\begin{array}{c}\text { Perhitungan } \\
\text { Calculation }\end{array}$ & $\begin{array}{c}\text { Basis penyesuaian } \\
\text { Adjustment base }\end{array}$ \\
\hline $0-2$ & Normal & $70 \%$ x anggaran \\
3 & $4 / 7 \times$ Basis normal & $4 / 7 \times 70 \%$ x anggaran \\
4 & $3 / 7 \times$ Basis normal & $3 / 7 \times 70 \%$ x anggaran \\
5 & $2 / 7 \times$ Basis normal & $2 / 7 \times 70 \%$ x anggaran \\
6 & $1 / 7 \times$ Basis normal & $1 / 7 \times 70 \%$ x anggaran \\
7 & Tanpa basis & Tanpa basis
\end{tabular}

Sumber : Perusahaan A dan B (2010); diolah kembali

Source: Companies A and B (2010); data reprocessed 
Tabel 3. Target dan estimasi produksi karet ideal

Table 3. Target and estimate of ideal rubber production

\begin{tabular}{|c|c|c|c|c|c|c|}
\hline \multirow[t]{2}{*}{$\begin{array}{c}\text { Perusahaan } \\
\text { Companys }\end{array}$} & \multirow{2}{*}{$\begin{array}{l}\text { Tahun } \\
\text { tanam } \\
\text { Planting } \\
\text { year }\end{array}$} & \multirow{2}{*}{$\begin{array}{l}\text { Posisi } \\
\text { bidang } \\
\text { sadap } \\
\text { Tapping } \\
\text { panel }\end{array}$} & \multirow[t]{2}{*}{$\begin{array}{l}\text { Klon } \\
\text { Clones }\end{array}$} & \multicolumn{2}{|c|}{$\begin{array}{c}\text { Produksi } \\
\text { (kg KK/ha) } \\
\text { Production } \\
(\mathrm{kg} / \mathrm{d} . \mathrm{r} / \mathrm{ha}) \\
\end{array}$} & \multirow[t]{2}{*}{$\begin{array}{c}\text { Keterangan } \\
\text { Remarks }\end{array}$} \\
\hline & & & & $\begin{array}{l}\text { Estimasi }^{*} \\
\text { Estimation }\end{array}$ & $\begin{array}{l}\text { Target } \\
\text { Target }\end{array}$ & \\
\hline A & 2005 & B0-1 & RRIM 712 & 1.043 & 1.540 & $\begin{array}{c}\text { Terlalu } \\
\text { tinggi }\end{array}$ \\
\hline A & 2003 & B0-2 & PB 260 & 1.128 & 1.538 & $\begin{array}{c}\text { Terlalu } \\
\text { tinggi }\end{array}$ \\
\hline A & 1999 & HO/BI & PB 330 & 1.141 & 1.324 & Tinggi \\
\hline B & 2005 & B0-1 & GT 1 & 1.597 & 1.827 & Tinggi \\
\hline B & 2001 & BO-2 & GT 1 & 2.630 & 2.714 & Tinggi \\
\hline B & 1999 & HO/BI & PB 260 & 2.169 & 2.320 & Tinggi \\
\hline $\mathrm{C}$ & 2005 & B0-1 & BPM 24 & 1.462 & 1.580 & Tinggi \\
\hline $\mathrm{C}$ & 2003 & B0-2 & GT 1 & 1.235 & 1.750 & $\begin{array}{l}\text { Terlalu } \\
\text { tinggi }\end{array}$ \\
\hline $\mathrm{C}$ & 1999 & $\mathrm{HO} / \mathrm{BI}$ & RRIM 712 & 1.852 & 1.663 & Ideal \\
\hline
\end{tabular}

Sumber : Perusahaan A, B, dan C (2013); diolah kembali

Source: Companies A, B, and C(2013); data reprocessed

*) Angka perkiraan berdasarkan potensi produksi tanaman

(Estimate value based on production potential of plant)

berdasarkan kondisi tanaman dengan memperhatikan jenis klon, umur, kesehatan, jumlah pokok disadap, sistem sadap, posisi panel, topografi lahan dan faktor lain yang berkaitan dengan musim (Siagian, 2010). Tabel 3 memperlihatkan nilai target produksi yang berada di atas perkiraan produksi ideal tanaman.

\section{Jenis Premi Penyadap}

Jenis premi diatur sedemikian rupa sehingga diharapkan mampu memotivasi penyadap mendapatkan hasil produksi yang optimal disertai dengan kualitas sadapan yang baik. Untuk mencapai tujuan tersebut maka macam-macam jenis premi penyadap secara umum terbagi ke dalam tiga, yaitu 1) premi sadap hari biasa (premi prestasi, premi kerajinan, dan premi khusus), 2) premi hari libur, dan 3) premi sadap bebas/sadap mati (free tapping). Masingmasing nilai tarif pada ketiga jenis premi tersebut dapat berbeda di masing-masing perusahaan yang berbeda tergantung pada kebijakan perusahaan. Gambaran umum dari ketentuan sistem premi pada ketiga perusahaan yang diamati diuraikan sebagai berikut:

\section{Premi sadap hari biasa \\ Premi prestasi}

Premi prestasi terbagi menjadi dua macam, yaitu premi kualitas dan premi kuantitas. Premi kualitas adalah premi yang diberikan kepada penyadap sebagai insentif terhadap fungsi predikat kelas penyadap. Premi kualitas diperhitungkan per hari sesuai jumlah hari kerja dinas penyadap. Sementara itu, premi kuantitas merupakan premi sadap yang dibayarkan berdasarkan atas pencapaian basis tugas yang ditetapkan oleh kebun. Nominal premi yang dibayarkan juga dihitung dengan mengacu pada predikat kelas penyadap. Bila seorang penyadap tidak mendapatkan basis tugasnya maka penyadap tersebut tidak mendapatkan premi kuantitas yang dimaksud. 
Predikat kelas A diberikan kepada penyadap dengan kualitas sadapan yang tergolong sangat baik. Predikat kelas B diberikan kepada penyadap dengan kualitas sadapan yang tergolong baik. Predikat kelas $\mathrm{C}$ diberikan kepada penyadap dengan kualitas sadapan yang buruk dan predikat kelas D diberikan kepada penyadap dengan kualitas sadapan yang sangat buruk. Predikat kelas penyadap C dan D pada prinsipnya tidak dikehendaki oleh perusahaan karena dalam jangka panjang akan menurunkan potensi produksi tanaman. Masing-masing predikat kelas tersebut ditentukan berdasarkan nilai kesalahan penyadapan (penalty point) yang diberikan perusahaan melalui mekanisme TAP kontrol. Masing-masing sistem dan standar penilaian TAP kontrol berbeda pada masing-masing kebun yang berbeda.

Pada perusahaan A premi kualitas tidak secara khusus melekat dengan predikat kelas penyadap, sementara pada perusahaan B dan C premi kualitas secara khusus melekat sesuai predikat kelas penyadap tanpa memperhatikan tercapai atau tidaknya basis tugas. Pada perusahaan $\mathrm{B}$, selain premi kualitas diberikan premi tambahan sebesar Rp 44.000,-/bulan khusus bagi penyadap kelas A jika perolehan produksi pada hari dinasnya telah mencapai basis tugas. Pada sistem sadap borong (hari libur atau sadap mati) ketentuan premi kualitas dan kuantitas tidak berlaku karena tidak adanya penilaian fungsi TAP kontrol. Karena secara khusus melekat pada predikat kelas penyadap maka premi kualitas akan sangat menentukan motivasi penyadap untuk melakukan penyadapan dengan baik. Ketentuan tarif premi kualitas pada ketiga perusahaan yang diamati disajikan pada Tabel 4.

Meski premi kuantitas juga diberlakukan ketika penyadap mampu mencapai basis tugasnya, namun perhitungan premi kuantitas pada masingmasing perusahaan yang diamati memiliki ketentuan yang berbeda. Pada perusahaan A premi kuantitas dihitung berdasarkan total capaian produksi per penyadap dikalikan dengan tarif premi yang sesuai dengan predikat kelas penyadap (Tabel 5). Pada perusahaan B premi kuantitas diberikan berdasarkan perolehan produksi di atas basis dengan mempertimbangkan kelas penyadap dan secara umum menghendaki perbedaan tarif premi terhadap sistem sadap atau posisi panel yang disadap (Tabel 6).

Tabel 4. Tarif premi kualitas berdasarkan kelas penyadap

Table 4. Rate of premium quality based on tapper class

\begin{tabular}{|c|c|c|c|c|}
\hline \multirow{3}{*}{$\begin{array}{l}\text { Kelas penyadap } \\
\text { Tapper class }\end{array}$} & \multicolumn{4}{|c|}{$\begin{array}{l}\text { Premi kualitas hari kerja ( } \mathrm{Rp} / \text { hari), pada perusahaan } \\
\text { Working day premium quality (Rp/day), on company }\end{array}$} \\
\hline & \multirow{2}{*}{ A } & \multirow{2}{*}{ B } & \multicolumn{2}{|c|}{$\mathrm{C}$} \\
\hline & & & B0 & $\mathrm{HO} / \mathrm{B} 1$ \\
\hline A & Belum diatur & $770(1,0)$ & $2.000(1,0)$ & $2.000(1,0)$ \\
\hline B & Belum diatur & $550(0,7)$ & $1.000(0,5)$ & $1.200(0,6)$ \\
\hline $\mathrm{C}$ & Belum diatur & $220(0,3)$ & Tidak dibayar & $800(0,4)$ \\
\hline $\mathrm{D}$ & Belum diatur & Tidak dibayar & Tidak dibayar & Tidak dibayar \\
\hline
\end{tabular}

Sumber : Perusahaan A, B, dan C (2010), diolah kembali

Source: Companies A, B, and C(2010); data reprocessed Angka dalam kurung merupakan indeks premi (Figures in brackets are premium index) 
Tabel 5. Tarif premi kuantitas atas dasar kelebihan basis di perusahaan A Table 5. Rate of premium quantity based on overbase premium in company A

\begin{tabular}{ccc}
\hline $\begin{array}{c}\text { Kelas penyadap } \\
\text { Tapper class }\end{array}$ & $\begin{array}{c}\text { Ideks premi } \\
\text { Premium index }\end{array}$ & $\begin{array}{c}\text { Tarif premi (Rp/ } / \mathrm{kg} \mathrm{KK}) \\
\text { Rate of premium (Rp/ } \mathrm{kg} \mathrm{d.r.} \text { ) }\end{array}$ \\
\hline A & 3,00 & 600 \\
B & 2,25 & 450 \\
C & 1,75 & 350 \\
D & 1,00 & 200 \\
\hline
\end{tabular}

Sumber : Perusahaan A (2010)

Source : Company A (2010)

Tabel 6. Tarif premi kuantitas berdasarkan kelas penyadap dan posisi bidang sadap di Perusahaan B

Table 6. Rate of premium quantity based on tapper class and tapping panel position in Company $B$

\begin{tabular}{|c|c|c|c|c|c|}
\hline \multirow[t]{2}{*}{$\begin{array}{c}\text { Uraian } \\
\text { Description }\end{array}$} & \multirow[t]{2}{*}{$\begin{array}{c}\text { Tanaman } \\
\text { Plant }\end{array}$} & \multirow[t]{2}{*}{$\begin{array}{c}\text { Bidang } \\
\text { sadapan } \\
\text { Tapping panel }\end{array}$} & \multicolumn{3}{|c|}{$\begin{array}{c}\text { Tarif premi di atas basis berdasarkan } \\
\text { kelas penyadap } \\
\text { (Rp/kg KK) } \\
\text { Rate of overbase premium based on } \\
\text { tapper class } \\
\text { (Rp/ } / \mathrm{kg} \text { d.r.) }\end{array}$} \\
\hline & & & $\mathrm{A}$ & $\mathrm{B}$ & $\mathrm{C}$ \\
\hline \multirow[t]{4}{*}{ 1. Lateks } & Tahun 1 *) & B0-1 & 495 & 385 & 220 \\
\hline & \multirow{3}{*}{ 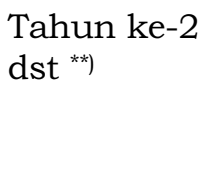 } & B0-1/BO-2 & 385 & 275 & 165 \\
\hline & & BI-1/BI-2 & 385 & 275 & 165 \\
\hline & & HO- $1 / \mathrm{HO}-2$ & 385 & 275 & 165 \\
\hline \multirow{4}{*}{$\begin{array}{l}\text { 2. Lump/ } \\
\text { Scrap }\end{array}$} & Tahun 1 *) & B0-1 & 440 & 275 & 165 \\
\hline & \multirow{3}{*}{$\begin{array}{l}\text { Tahun ke-2 } \\
{\left.\text { dst }{ }^{* *}\right)}\end{array}$} & B0-1/B0-2 & 330 & 165 & 138 \\
\hline & & BI-1/BI-2 & 330 & 165 & 138 \\
\hline & & HO- $1 / \mathrm{HO}-2$ & 330 & 165 & 138 \\
\hline
\end{tabular}

Premi kuantitas pada perusahaan C dihitung dengan mengalikan kelebihan basis tugas dengan tarif premi yang berlaku (Tabel 7). Pada setiap penyadap kelebihan basis dihitung setiap akhir bulan tanpa memperhitungkan produksi pada hari minggu dan hari libur. Besarnya tarif premi kuantitas dibedakan berdasarkan hasil lateks dan lump serta membedakan tarif sesuai posisi panel yang disadap. Penyadapan pada posisi panel yang lebih sulit (HO/BI atau double cut), tarif premi pada predikat kelas penyadap B, C, dan D diatur lebih tinggi daripada penyadapan di posisi panel B0. Pada perusahaan $\mathrm{C}$, tidak dibenarkan menggunakan penyadap kelas $\mathrm{C}$ pada panel B0, tetapi lebih diutamakan penyadap kelas A dan B. 
Tabel 7. Tarif premi kuantitas atas dasar kelebihan basis dan kelas penyadap di Perusahaan C Table 7. Rate of premium quantity based on overbase premiums and tapper class in Company C

\begin{tabular}{|c|c|c|c|}
\hline \multirow[t]{3}{*}{$\begin{array}{c}\text { Kelas penyadap } \\
\text { Tapper class }\end{array}$} & \multicolumn{3}{|c|}{$\begin{array}{l}\text { Tarif premi kuantitas } \\
(\mathrm{Rp} / \mathrm{kg} \mathrm{KK}) \\
\text { Rate of premium quantity } \\
(\mathrm{Rp} / \mathrm{kg} \text { d.r.) }\end{array}$} \\
\hline & \multicolumn{2}{|c|}{ Latex } & \multirow{2}{*}{ Lump } \\
\hline & B0 & $\mathrm{HO} / \mathrm{BI}$ & \\
\hline A & $3.000(1,0)$ & $3.000(1,0)$ & $2.000(1,0)$ \\
\hline B & $1.500(0,5)$ & $1.800(0,6)$ & $2.000(1,0)$ \\
\hline $\mathrm{C}$ & $750(0,25)$ & $1.200(0,4)$ & $2.000(1,0)$ \\
\hline $\mathrm{D}$ & Tidak dibayar & $750(0,25)$ & $2.000(1,0)$ \\
\hline
\end{tabular}

Sumber : Perusahaan C (2010)

Source : Company C(2010)

Angka dalam kurung merupakan indeks premi (Figures in brackets are premium index)

Pada prinsipnya penerapan premi kualitas membantu perusahaan mendorong penyadap untuk menghasilkan kualitas sadapan yang baik. Kemelekatannya pada fungsi predikat kelas penyadap menjadi insentif bagi penyadap melakukan penyadapan sesuai norma. Penerapan jenis premi ini harus dibantu dengan nilai tarif yang berbeda signifikan antara penyadap terbaik dan terburuk sehingga motivasi penyadap untuk menghasilkan kualitas sadap yang baik semakin meningkat. Selain itu perlu disadari bahwa tarif premi harus sebanding dengan tingkat kesulitan penyadapan, baik terkait dengan topografi, luas lahan maupun ketinggian bidang sadap. Pada tingkat kesulitan penyadapan yang lebih tinggi (topografi berbukit, hanca luas, atau posisi panel yang tinggi) tarif premi seharusnya diatur lebih besar dari kondisi normal sebagaimana diterapkan pada perusahaan $\mathrm{C}$. Tarif premi harus diatur sedemikian rupa sehingga motivasi penyadap tidak menurun ketika beban tugas yang diberikan meningkat.

\section{P Premi kerajinan}

Pada prinsipnya premi kerajinan ditujukan untuk mengukur kedisiplinan dan loyalitas penyadap dalam memelihara ancak sadapnya. Secara umum, dari ketiga perusahaan yang diamati premi kerajinan mencakup premi kehadiran, premi kutip lump, premi pungut tetesan sore, premi pengutipan scrap, premi cuci mangkok, premi anjang-anjang, dan premi pemeliharaan sepeda (jika sepeda merupakan standar alat angkut produksi yang ditetapkan perusahaan).

Tidak semua perusahaan yang diamati mengatur secara penuh semua jenis premi ini. Pada Perusahaan A, premi kerajinan yang diterapkan mencakup premi kutip lump, premi kutip scrap, premi cuci mangkok, premi anjang-anjang, dan premi pemeliharaan sepeda. Premi kutip lump dibayar Rp 2.000,--/hanca kepada penyadap yang hanya melaksanakan kutip lump mundur untuk tiap hari pengutipan. Premi pengutipan scrap diberikan $\mathrm{Rp} 500$,- per penyadap per hari jika penyadap menyetor scrap $\geq 0,4 \mathrm{~kg}$ basah. Premi cuci mangkok diberlakukan satu kali dalam dua bulan untuk seluruh hanca dengan tarif $\mathrm{Rp} 20$,/mangkok. Premi anjang-anjang diberikan bagi penyadap yang memakai anjang-anjang sebesar Rp 4.000,-/bulan. Premi pemeliharaan sepeda dibayarkan $\mathrm{Rp}$ 15.000,-/bulan. Pada Premi ini diberikan bagi penyadap yang masih menggunakan sepeda sebagai kendaraan dinasnya. Premi pungut tetesan sore dan premi kehadiran belum diatur pada Perusahaan A.

Lain halnya dengan Perusahaan B, jenis premi kerajinan yang diterapkan adalah premi pungut tetesan sore dan premi kehadiran. Premi pungut tetesan sore diberikan kepada penyadap setara dengan 1,5 jam kerja lembur dan diperhitungkan sesuai tarif jam kerja lembur karyawan golongan 1A/0. Jumlah produksi tetesan 
sore menjadi tambahan produksi pada hari tersebut dan diperhitungkan normal sebagai pengali premi. Premi ini didapat oleh penyadap ketika tanaman yang disadap mendapatkan aplikasi stimulan sehingga produksi pada saat penyadapan melimpah. Premi kehadiran diberikan kepada penyadap yang jumlah produksi pada hari dinasnya telah mencapai basis tugas yang ditetapkan (dalam satu bulan). Premi ini diberikan hanya kepada penyadap dengan predikat kelas A sebagai bentuk motivasi untuk memenuhi kehadiran pada hari dinasnya. Besarnya premi kehadiran yang diberikan adalah Rp 44.000 per bulan, dan berlaku secara proporsional sesuai tingkat kehadiran pada hari dinasnya. Premi kutip lump pada Perusahaan B tidak diperhitungkan khusus ke dalam jenis premi kehadiran melainkan sudah termasuk ke dalam perhitungan premi prestasi (Tabel 6).

Pada perusahaan $\mathrm{C}$, penerapan jenis premi kerajinan diberikan melalui premi pungut tetesan sore dan premi kutip scrap. Premi pungut kutipan sore lebih dikenal dengan premi tunggu dan dibayar sebesar $\mathrm{Rp} 700,-/$ jam dengan maksimum jam tunggu adalah 54 jam dalam sebulan. Premi ini umumnya didapat oleh penyadap ketika tanaman mendapat perlakuan stimulan.
Adapun premi kutip scrap diberikan adalah Rp 2.000-3.500,-/kg KK. Sebagaimana pada Perusahaan B, premi kutip lump tidak diatur khusus ke dalam jenis premi kerajinan, akan tetapi sudah termasuk ke dalam perhitungan premi prestasi. Tabel 8 memperlihatkan jenis dan tarif premi kerajinan pada ketiga kebun yang diamati.

Salah satu kelemahan manajemen perkebunan adalah lambannya tingkat penyesuaian upah dan sistem yang mengaturnya (Mahyudin dan Majdah, 2010). Prinsip dasar bahwa tarif dan jenis premi harus mampu mendorong pencapaian produksi yang optimal dan kualitas sadap yang baik harus secara nyata diterapkan sehingga tidak menjadi unsur inefesiensi perusahaan. Oleh karena itu, tarif dan jenis premi dapat diatur secara relevan sesuai dengan perubahan lingkungan perusahaan. Perusahaan harus mampu memilah jenis premi mana yang berdampak langsung pada produksi dan kualitas sadapan serta mana yang hanya sebatas pada atribut kedisiplinan penyadap dalam pengelolaan ancaknya. Diantara jenis premi kerajinan yang paling utama memberikan manfaat bagi perusahaan adalah 1) premi kehadiran, 2) premi kutip lump, 3) premi pungut tetesan sore, dan 4) premi scrap.

Tabel 8. Tarif premi kerajinan di perusahaan A, B, dan C

Table 8. Rate of premium on discipline in companies $A, B$, and $C$

\begin{tabular}{|c|c|c|c|}
\hline \multirow{2}{*}{$\begin{array}{l}\text { Jenis kerajinan } \\
\text { Kinds of discipline }\end{array}$} & \multicolumn{3}{|c|}{$\begin{array}{l}\text { Tarif premi pada perusahaan } \\
\text { Rate of premium in company }\end{array}$} \\
\hline & A & $\mathrm{B}$ & C \\
\hline Kehadiran (Rp/bulan) & - & 44.000 & - \\
\hline Kutip lump & 2.000 (Rp/hanca) & (Tabel 6) & (Tabel 7) \\
\hline Pungut tetesan sore & $500(\mathrm{Rp} / \mathrm{kg} \mathrm{KK})$ & $\begin{array}{r}\text { *) } 1,5 \text { jam lembur } \\
(\mathrm{Rp} / \mathrm{HK})\end{array}$ & 700 (Rp/jam) \\
\hline Kutip scrap & $\begin{array}{r}500 \\
(\mathrm{Rp} / \text { penyadap/hari) }\end{array}$ & - & $\begin{array}{r}2.000-3.500 \\
(\mathrm{Rp} / \mathrm{kg} \mathrm{KK})\end{array}$ \\
\hline $\begin{array}{l}\text { Cuci mangkok } \\
\text { (Rp/mangkok/2 bulan) } \\
\text { Anjang-anjang (Rp/bulan) }\end{array}$ & 20 & - & - \\
\hline Anjang-anjang (Rp/bulan) & 4.000 & - & - \\
\hline $\begin{array}{l}\text { Pemeliharaan sepeda } \\
\text { (Rp/bulan) }\end{array}$ & 15.000 & - & - \\
\hline
\end{tabular}


Premi kehadiran menjadi penting karena dalam kondisi jumlah penyadap yang terbatas pencapaian target produksi hanya bisa dilakukan dengan memenuhi jumlah hari sadap. Semakin rendah tingkat kehadiran penyadap maka semakin kecil peluang perusahaan mencapai target produksi yang telah ditetapkan. Pada ketiga perusahaan yang diamati jenis premi kehadiran tidak diatur secara khusus. Premi kutip lump, premi pungut tetesan sore, dan premi kutip scrap adalah premi yang diberikan agar potensi produksi tanaman tergali optimal. Premi kutip lump penting karena menambah hingga $2-3 \mathrm{~kg}$ KK produksi harian penyadap. Premi pungut tetesan sore penting karena merupakan insentif bagi penyadap untuk mengutip produksi di luar jam kerja dinasnya. Bagi perusahaan, tetesan sore dalam bentuk lateks penting karena memiliki harga jual yang lebih tinggi. Premi kutip scrap dianggap penting karena selain memiliki fungsi dalam memperlancar aliran sadap juga berpotensi memberikan tambahan 0,10-0,15 kg KK per hari (pada tanaman yang disadap di panel bawah).

\section{$\square \quad$ Premi khusus}

Premi khusus bertujuan untuk mendukung proses penyadapan memperoleh hasil yang optimal. Premi ini mencakup premi sadap bukaan baru, premi stimulansia, premi pindah panel, dan premi pikul. Premi sadap bukaan baru merupakan premi yang diberikan kepada penyadap yang melakukan penyadapan di tanaman yang baru memasuki tahun pertama sadap (tanaman promosi). Pada Perusahaan A, pelaksanaan kegiatan buka sadap hanya boleh dilakukan oleh penyadap dengan predikat kelas A. Ketentuan premi sadap bukaan baru pada Perusahaan A diatur dengan membedakan tarif antara 3 bulan pertama dan 3 bulan kedua (Tabel 9). Setelah melewati enam bulan sadap dan prestasi per penyadap telah mencapai $>15 \mathrm{~kg} \mathrm{KK}$, maka sistem premi kembali berlaku seperti normal.

Pada Perusahaan B dan C, premi sadap bukaan baru mencakup pemberian premi untuk kegiatan menggambar bidang sadap, buka sadap, dan pasang alat. Premi untuk kegiatan ini dibayar setara dengan 1,0-1,5 HK/Hanca. Pada Kebun B, ketentuan premi sadap selanjutnya diatur untuk tiga bulan sadap dan menghendaki perbedaan tarif premi berdasarkan predikat kelas penyadap. Penyadap kelas A diberikan premi setara dengan rata-rata premi penyadap yang ada di afdelingnya. Sementara penyadap Kelas B dan C diberikan tarif premi masing-masing sebesar $80 \%$ dan $60 \%$ dari rata-rata premi penyadap di afdelingnya (Tabel 10). Premi sadap bukaan baru pada bulan keempat dan seterusnya kembali berlaku seperti normal. Adapun pada perusahaan C, ketentuan premi sadap bukaan baru selanjutnya berlaku selama satu tahun pertama dan dibedakan menjadi dua jenis premi, yaitu premi kualitas dan premi kuantitas yang masing-masing ditentukan sebesar Rp 2.500,-/ HK dan Rp 500,-/ kg KK.

Tabe1 9. Tarif premi sadap bukaan baru (tanaman promosi) di Perusahaan A Table 9. Rate of premium at new tapping area (promotion plant) in Company A

\begin{tabular}{lc}
\multicolumn{1}{c}{$\begin{array}{c}\text { Uraian } \\
\text { Description }\end{array}$} & $\begin{array}{c}\text { Tanaman promosi } \\
\text { Promotion plant }\end{array}$ \\
\hline Buka sadap (Rp/pohon) & 125 \\
Pasang alat (Rp/pohon) & 25 \\
Premi kualitas (Rp/hari) & $*$ ) 7.500 dan **) 5.000 \\
Premi kuantitas (Rp/kg KK) & 600 \\
Cuci mangkok (Rp/bh/bulan) & 10 \\
Kutip lump (Rp/hari) & 2.000 \\
Kutip scrap (Rp/hari) & 500 \\
Anjang-anjang (Rp/bulan) & 4.000 \\
Pemeliharaan sepeda (Rp/bulan) & 15.000 \\
\hline Sumber : Perusahaan A (2010) & $*$ selama 3 bulan pertama (forthe first three months) \\
Source: Company A (2010) & $* *$ selama 3 bulan kedua (forthe second three months)
\end{tabular}


Tabel 10. Tarif premi sadap bukaan baru di perusahaan B

Table 10. Rate of premium at new tapping area in company $B$

\begin{tabular}{cl}
\hline $\begin{array}{c}\text { Kelas penyadap } \\
\text { Tapper class }\end{array}$ & \multicolumn{1}{c}{ Tarif premi } \\
Premium rate
\end{tabular}

Sumber : Perusahaan B (2010)

Source: Company B (2010)

Untuk menjaga kualitas sadap pada tanaman yang baru dibuka sadap maka sebaiknya digunakan penyadap dengan predikat kelas A. Tarif premi kualitas yang diberlakukan harus dapat diatur lebih besar dari tarif premi kualitas pada kondisi normal. Basis tugas sebagaimana diberlakukan pada sadap biasa sebaiknya ditiadakan untuk mencegah adanya beban psikologis penyadap mendapatkan hasil sadap sesuai basis tugas tersebut. Ketentuan premi ini sebaiknya diberikan selama satu tahun pada tahun sadap pertama.

Jenis premi berikutnya yaitu premi pikul. Premi pikul pada umumnya hanya diberikan kepada penyadap yang melakukan penyadapan di areal berbukit atau berlokasi jauh dari tempat pengumpulan hasil (TPH). Pada Perusahaan A, premi pikul hanya berlaku pada kebun yang memiliki areal berbukit. Besarnya tarif premi pikul pada Perusahaan A adalah Rp. 50,- per $\mathrm{kg}$ KK per $\mathrm{km}$ jalan pikul. Pada Perusahaan B, premi pikul diatur sedemikian rupa berdasarkan tingkat kemiringan. Areal berbukit dengan tingkat kemiringan $26-50 \%$ diberikan $50 \%$ tarif normal, sementara areal curam dengan tingkat kemiringan $>50 \%$ diberikan $100 \%$ tarif normal. Tarif premi pikul pada Perusahaan B dibedakan antara premi pikul lateks dan lump, yaitu masing-masing sebesar Rp 110,-/kg KK dan Rp. 55/kg KK (Tabel 11). Adapun pada Perusahaan C, premi pikul diberikan kepada penyadap yang lokasi hancanya jauh dari TPH $(>1 \mathrm{~km})$ dengan tarif Rp. 150,-/kg KK. Untuk jarak yang memerlukan angkutan pribadi tarif premi diatur sesuai kebijakan kebun. Pada areal datar/bergelombang tidak diberikan premi pikul.

Premi pindah panel juga mencakup premi untuk kegiatan menggambar bidang sadap, buka sadap, dan pasang alat. Tarif premi untuk kegiatan tersebut dibayar setara dengan 1,0 HK. Kegiatan tersebut berlaku secara umum saat melakukan pindah panel di ketiga kebun yang diamati. Namun khusus pada Kebun A diberikan tamabahan premi pindah panel sebesar Rp 2.200 ,- per hanca.

Jenis premi selanjutnya yaitu premi stimulansia. Pada perusahaan A, premi stimulansia dibayar setara dengan 1,0 HK

Tabel 11. Tarif premi pikul berdasarkan tingkat kemiringan areal di perusahaan B Table 11. Rate of premium of rubber carrying based on land slope in company $B$

\begin{tabular}{cccc}
\hline $\begin{array}{c}\text { Kemiringan lahan } \\
\text { Land sloping } \\
(\%)\end{array}$ & $\begin{array}{c}\text { Topografi lahan } \\
\text { Land topography }\end{array}$ & $\begin{array}{c}\text { Persentase terhadap tarif } \\
\text { normal } \\
\text { Percentage of normal rate } \\
(\%)\end{array}$ & $\begin{array}{c}\text { Keterangan } \\
\text { Remarks }\end{array}$ \\
\hline $0-25$ & Datar/bergelombang & 0 & Tarif premi \\
$26-50$ & Berbukit & 50 & pikul lateks \\
$>50$ & Curam & 100 & Rp. 110,- $/ \mathrm{kg}$ \\
& & & KK dan lump \\
& & & Rp 55,- $/ \mathrm{kg} \mathrm{KK}$. \\
\hline
\end{tabular}

Sumber : Perusahaan B (2010).

Source : Company B (2010). 
per hanca per aplikasi untuk sistem groove (GEA) pada panel bawah atau 2,0 HK per hanca per aplikasi untuk sistem scrapping (SES) pada panel atas. Pada Perusahaan B, premi stimulansia dibayar setara dengan $0,67 \mathrm{HK}$ per hanca per aplikasi untuk sistem groove dan 1,0 HK per hanca per aplikasi untuk sistem scrap. Pada perusahaan C premi stimulansia dibayar setara dengan 1,0 HK per hanca per aplikasi untuk sistem groove dan 1,5 - 2,0 HK per hanca per aplikasi untuk sistem scrapping. Tabel 12 menyajikan ketentuan tarif premi stimulansia berdasarkan sistem aplikasi pada ketiga perusahaan yang diamati.

\section{Premi sadap hari libur}

Premi hari libur merupakan premi yang diberikan kepada penyadap yang melakukan pekerjaannya di hari libur. Pembayaran premi hari libur ditentukan berdasarkan jumlah produksi kg KK per penyadap (lateks, kompo, dan scrap) dikalikan dengan tarif premi yang ditentukan oleh manajemen kebun. Pada Perusahaan A, tarif premi sadap hari libur ditentukan sebesar Rp 1.000,- per kg KK. Perusahaan menghendaki persentase lump yang dibawa maksimal 28\% dari jumlah produksi per penyadap. Jika persentase lump lebih dari 28\% maka kelebihan lump tersebut tetap akan dibayar per kg kering. Pada penyadapan hari libur tidak berlaku ketentuan premi kutip lump dan premi kutip scrap. Penyadapan pada hari libur mendapatkan ketentuan pelepasan hak yang besarannya Rp 20.000,- per penyadap per hari atau setara dengan 3 jam kerja lembur.
Pada Perusahaan B, ketentuan premi sadap hari libur diatur berdasarkan predikat kelas penyadap dan menghendaki perbedaan tarif antara produksi lateks dan lump (Tabel 13). Pada tahun pertama tarif premi sadap hari libur untuk produksi lateks diberikan sebesar Rp 1.650,-/kg KK untuk kelas A, Rp 1.320,-/ kg KK untuk kelas B, dan Rp 880,-/kg KK untuk kelas C. Untuk produksi lump, pada tahun pertama tarif premi diberikan sebesar Rp 1.100,-/kg KK untuk kelas A, Rp 880,-/kg KK untuk kelas B, dan Rp 660,-/kg KK untuk kelas C. Pada tahun berikutnya tarif premi diberikan untuk produksi lateks diberikan sebesar Rp 1.320,-/kg KK untuk kelas A, Rp 1.100,-/kg KK untuk kelas B, dan Rp 660,-/ kg KK untuk kelas C. Untuk produksi lump tarif premi diberikan sebesar Rp 825,-/kg KK untuk kelas A, Rp 715,-/kg KK untuk kelas B, dan Rp 550,-/kg KK untuk kelas C.

Sementara pada Perusahaan C, sebagaimana pada Perusahaan A, untuk menjaga pemakaian kulit pada tahun pertama penyadapan pada hari libur tidak dilakukan. Premi sadap hari libur diperhitungkan berdasarkan berat $\mathrm{kg} \mathrm{KK}$ dan dibedakan antara produksi lateks dan lump tanpa membedakan predikat kelas penyadap. Besar tarif premi sadap hari libur pada kebun $\mathrm{C}$ berkisar Rp 2.000,- hingga Rp 4.000,- per kg KK untuk produksi lateks, sementara untuk produksi lump ditentukan sebesar 50\% dari tarif premi lateks. Premi diatur dengan sistem borongan tanpa memberlakukan basis tugas kepada penyadap.

Tabel 12. Tarif premi stimulansia berdasarkan sistem aplikasi di perusahaan A, B, dan C Table 12. Rate of premium stimulant based on application system in companies $A, B$, and $C$

\begin{tabular}{ccc}
\hline & \multicolumn{2}{c}{$\begin{array}{r}\text { Tarif premi berdasarkan sistem aplikasi stimulan } \\
\text { (Rp/hanca/aplikasi) }\end{array}$} \\
$\begin{array}{c}\text { Perusahaan } \\
\text { Company }\end{array}$ & $\begin{array}{c}\text { Rate of premium based on stimulant application system } \\
\text { (Rp/task/application) }\end{array}$ \\
\cline { 2 - 3 } A & Groove & Scrapping \\
B & $1,0 \mathrm{HK}$ & $2 \mathrm{HK}$ \\
C & $0,67 \mathrm{HK}$ & $1 \mathrm{HK}$ \\
$1,0 \mathrm{HK}$ & $1,5-2,0 \mathrm{HK}$ \\
\hline
\end{tabular}

Sumber : Perusahaan A, B, dan C (2010); diolah kembali

Source : Companies A, B, and C(2010); data reprocessed 
Tabel 13. Tarif premi sadap hari libur di perusahaan B

Table 13. Rate of tapping premium on holiday in company $B$

\begin{tabular}{|c|c|c|c|c|c|c|}
\hline \multirow{3}{*}{$\begin{array}{l}\text { Tanaman } \\
\text { Plant }\end{array}$} & \multicolumn{3}{|c|}{$\begin{array}{l}\text { Premi lateks } \\
\text { (Rp/kg KK) } \\
\text { Latex premium } \\
\text { (Rp/kg d.r.) }\end{array}$} & \multicolumn{3}{|c|}{$\begin{array}{l}\text { Premi lump } \\
\text { (Rp/kg KK) } \\
\text { Lump premium } \\
\text { (Rp/kg d.r.) }\end{array}$} \\
\hline & \multicolumn{3}{|c|}{$\begin{array}{l}\text { Kelas penyadap } \\
\text { Tapper class }\end{array}$} & \multicolumn{3}{|c|}{$\begin{array}{l}\text { Kelas penyadap } \\
\text { Tapper class }\end{array}$} \\
\hline & A & $\mathrm{B}$ & $\mathrm{C}$ & A & $\mathrm{B}$ & $\mathrm{C}$ \\
\hline Tahun ke-1 & 1.650 & 1.320 & 880 & 1.100 & 880 & 660 \\
\hline Tahun ke-2 dst & 1.320 & 1.100 & 660 & 825 & 715 & 550 \\
\hline
\end{tabular}

Sumber : Perusahaan B (2010)

Source : Company B (2010)

Pada prinsipnya penyadapan hari libur bertujuan mengoptimalkan hari sadap dalam satu bulan sehingga peluang tercapainya target produksi semakin besar. Selain itu penyadapan hari libur juga dilakukan atas dasar pertimbangan untuk menutupi kekurangan produksi pada harihari tertentu dimana target produksi tidak tercapai. Dengan alasan tersebut seringkali perusahaan mengabaikan fungsi pengawasan baik oleh afdeling maupun TAP kontrol. Penyadapan pada hari libur sebaiknya tidak dilakukan pada tahun pertama penyadapan, sebab kualitas sadap pada tahun pertama akan sangat menentukan potensi hasil pada tahuntahun berikutnya. Jika kualitas sadap pada tahun-tahun awal penyadapan (kulit perawan) rendah maka dapat dipastikan penyadapan pada tahun-tahun berikutnya (kulit pulihan) akan rendah juga (Siagian, 2011). Pertimbangan predikat kelas penyadap terhadap penentuan tarif premi diperlukan untuk menjaga motivasi penyadap melakukan penyadapan dengan baik. Peran pengawasan juga perlu diperhatikan untuk mengantisipasi kemungkinan penyadap mengalihkan produksi hari sebelumnya ke hari sadap libur (terutama produksi lump).

\section{Premi sadap bebas}

Pada saat umur ekonomi suatu hamparan blok tanaman dikatakan telah habis ( $>20$ tahun) yang dapat diukur dari indikator 1) produksi yang kecil, 2) ketersediaan kulit yang minim, dan 3) tegakan pohon per hektar yang rendah, setiap kebun umumnya menetapkan sistem sadap bebas (free tapping system) atau sering disebut dengan sadap mati pada tanamannya. Areal-areal yang akan dilaksanakan sadap bebas harus diatur sedemikian rupa karena terkait dengan perencanaan penanaman ulang (replanting) kebun. Areal-areal tersebut biasanya ditetapkan selama $2-3$ tahun sebelum tanaman ditebang.

Pada ketiga perusahaan yang diamati, umumnya manajemen tetap mengatur sistem sadap yang digunakan, namun pada kenyataannya seringkali penyadap melakukan penyadapan tanpa memperhatikan ketentuan tersebut. Orientasi penyadap dalam hal ini lebih diutamakan pada penggalian produksi secara optimal. Perusahaan umumnya memberikan dua skema penyadapan yang berbeda, yaitu penyadapan yang dilakukan oleh tenaga pemborong (TP) atau penyadapan yang dilakukan oleh tenaga sendiri (TS). Apabila penyadapan dilakukan oleh tenaga pemborong maka perhitungan premi sadap bebas tidak memberlakukan basis tugas, sedangkan apabila dilaksanakan oleh tenaga sendiri (kecuali pada kebun A), maka tetap diberlakukan basis tugas. Tarif premi untuk tenaga pemborong ditentukan sesuai dengan kesepakatan antara perusahaan dan pemborong dan besarnya dipengaruhi oleh fluktuasi harga karet. Pada artikel ini skema yang dibahas adalah skema yang tetap mengacu pada penggunaan tenaga sendiri.

Pada Perusahaan A, diberikan tarif premi sebesar Rp 500,- per kg KK tanpa membedakan produksi lateks dan lump. Premi dihitung dengan mengalikan total jumlah produksi yang didapat penyadap dengan tarif premi tersebut. Sementara pada Perusahaan B, tarif premi dibedakan antara 
Tabel 14. Tarif premi sadap bebas/sadap mati di Perusahaan B Tabel 14. Rate of premium free tapping/heavy tapping in Company $B$

\begin{tabular}{ccc}
\hline & \multicolumn{3}{c}{$\begin{array}{c}\text { Tarif premi sadap bebas } \\
\text { (Rp/kg KK) } \\
\text { Rate of premiums } \\
\text { (Rp/lisg d.r.) }\end{array}$} \\
\hline Plant condition & \multicolumn{3}{c}{ Lump/scrap } \\
\cline { 2 - 3 } & 2.000 & 1.750 \\
$\mathrm{~T}-3$ & 2.500 & 2.000 \\
\hline
\end{tabular}

Sumber : Perusahaan B (2010)

Source : Company B (2010)

$\mathrm{T}-1,2,3 \ldots \mathrm{n}=$ Tahun $\mathrm{ke}-1,2,3, \ldots \mathrm{n}$ sebelum peremajaan $(1,2,3, \ldots$ nears before replanting $)$

produksi lateks dan lump dan menghendaki perbedaan tarif antara 3 tahun dan $2-1$ tahun sebelum tanaman ditumbang (Tabel 14). Adapun pada Perusahaan C, tarif premi sadap bebas diatur sebagaimana premi sadap borong pada hari libur yaitu sebesar Rp 2.000,- hingga Rp 4.500,- untuk produksi lump dan Rp 1.000,- hingga Rp 2.250,- untuk produksi lump. Pada Perusahaan $\mathrm{B}$ dan $\mathrm{C}$ premi dihitung berdasarkan atas kelebihan basis, yaitu jumlah produksi di atas basis dikalikan dengan tarif premi.

\section{Premi lain yang berkaitan dengan operasional panen}

Untuk mendukung tercapainya kualitas sadap yang baik, premi juga diberikan kepada pekerja lain yang berkaitan dengan operasional panen. Pemberian premi ini ditujukan sebagai insentif kerja yang diberikan dalam membantu dan mengawal aktivitas penyadapan. Perhitungan premi tersebut didasarkan atas prestasi yang dicapai oleh penyadap yang diawasi dan diukur melalui indikator produksi yang dicapai. Di antara pekerja lain yang berkaitan dengan operasional panen, yaitu mandor besar/mandor 1, mandor sadap, TAP kontrol induk, TAP kontrol afdeling, koordinator produksi, krani afdeling, krani lateks, pembantu krani di TPH, dan pekerja TPH.

Pada Perusahaan A, premi mandor besar diberikan sebesar $150 \%$ dari rata-rata premi mandor sadap yang dibawahinya. Premi mandor sadap diberikan sebesar $150 \%$ dari rata-rata premi penyadap yang dibawahinya. Premi pembantu krani diberikan sebesar $125 \%$ dari rata-rata premi penyadap yang diadministrasikannya. Premi pekerja tempat pengumpulan hasil (TPH) diberikan $75 \%$ dari rata-rata premi penyadap di TPH-nya. Kepada mandor sadap diberikan premi khusus percepatan jam kerja per bulan. Krani lateks mengerjakan dua sampai tiga kemandoran penyadap. Sementara pekerja TPH bertanggung jawab terhadap minimal dua kemandoran.

Pada Perusahaan B, premi mandor besar adalah $150 \%$ dari rata-rata premi mandor sadap yang dibawahinya. Premi mandor sadap diberikan sebesar 200\% dari rata-rata premi penyadap yang dibawahinya. Premi krani afdeling diberikan sebesar 90\% dari rata-rata premi mandor sadap. Premi pembantu krani diberikan $125 \%$ dari ratarata premi penyad a y a n g diadministrasikannya. Premi koordinator produksi diberikan sebesar $75 \%$ dari premi krani afdeling. Premi TAP kontrol diberikan $125 \%$ dari rata-rata premi mandor sadap yang dinilainya, serta premi satpam afdeling diberikan sebesar 90\% dari rata-rata premi penyadap.

Pada Perusahaan C, premi mandor besar ditentukan $200 \%$ dari rata-rata premi penyadap. Premi koordinator produksi sebesar $175 \%$ dari rata-rata premi penyadap sub/afdeling. Premi mandor sadap diberikan sebesar $150 \%$ dari rata-rata premi penyadap yang dibawahinya. Premi TAP kontrol afdeling diberikan sebesar $175 \%$ dari ratarata premi penyadap sub/afdeling. Premi TAP kontrol induk diberikan sebesar 225\% dari rata-rata premi seluruh penyadap kebun. Selain itu juga terdapat premi pekerja TPH dan pengantar lateks yang terkait dengan kebersihan TPH, tingkat losses produksi dan kualitas lateks yang 
dikawalnya. Besarnya premi ditentukan berdasarkan kelas, dimana kelas A diberikan premi sebesar $100 \%$ dari rata-rata premi penyadap yang dilayaninya dan kelas B diberikan premi sebesar $80 \%$ dari ratarata premi penyadap yang dilayaninya. Secara umum ketentuan tarif premi pekerja lain yang berkaitan dengan operasional panen disajikan pada Tabel 15 .

Pemberian premi pekerja lain yang berkaitan dengan operasional panen harus menekankan pada kontribusinya terhadap kegiatan penyadapan, sehingga pemberian premi tidak memberikan kesan inefisiensi bagi perusahaan. Di antara sejumlah jenis premi pekerja lain yang berkaitan dengan operasional panen, beberapa jenis premi yang dianggap penting adalah premi mandor besar, premi mandor sadap, premi TAP kontrol, premi krani afdeling, premi pembantu krani, premi pekerja TPH, dan premi penjaga afdeling. Premi mandor besar dan mandor sadap penting karena berkaitan dengan pengawasan kegiatan penyadapan. Premi TAP kontrol penting karena berkaitan dengan sistem monitoring dan verifikasi penyadapan. Premi krani afdeling dan pembantu krani penting karena berkaitan dengan pencatatan administrasi produksi. Premi pekerja TPH penting karena berkaitan dengan pelayanan pengumpulan produksi di TPH. Premi penjaga afdeling penting karena berkaitan dengan keamanan produksi.

Tabel 15. Premi lain yang berkaitan dengan operasional panen di perusahaan A, B, dan C Table 15. Other premium related with harvesting activities in company $A, B$, and $C$

\begin{tabular}{|c|c|c|c|}
\hline \multirow{2}{*}{$\begin{array}{l}\text { Uraian jenis premi } \\
\text { Description of } \\
\text { premiums kinds }\end{array}$} & \multicolumn{3}{|c|}{$\begin{array}{c}\text { Perusahaan } \\
\text { Company }\end{array}$} \\
\hline & A & $\mathrm{B}$ & $\mathrm{C}$ \\
\hline Mandor besar & $\begin{array}{l}150 \% \times \text { rata-rata } \\
\text { premi mandor sadap }\end{array}$ & $\begin{array}{l}150 \% \times \text { rata-rata } \\
\text { premi mandor sadap }\end{array}$ & $\begin{array}{l}200 \% \times \text { rata-rata } \\
\text { premi penyadap }\end{array}$ \\
\hline Mandor sadap & $\begin{array}{l}150 \% \text { x rata-rata } \\
\text { premi penyadap yang } \\
\text { dibawahi }\end{array}$ & $\begin{array}{l}200 \% \text { x rata-rata } \\
\text { premi penyadap yang } \\
\text { dibawahi }\end{array}$ & $\begin{array}{l}150 \% \text { x rata-rata } \\
\text { premi penyadap } \\
\text { yang dibawahi }\end{array}$ \\
\hline TAP kontrol induk & - & - & $\begin{array}{l}225 \% \times \text { rata-rata } \\
\text { premi penyadap } \\
\text { kebun }\end{array}$ \\
\hline TAP kontrol afdeling & - & $\begin{array}{l}125 \% \times \text { rata-rata } \\
\text { premi mandor sadap }\end{array}$ & $\begin{array}{l}175 \% \text { x rata-rata } \\
\text { premi penyadap } \\
\text { afdeling }\end{array}$ \\
\hline Koordinator produksi & - & $\begin{array}{l}75 \% \times \text { rata-rata premi } \\
\text { krani afdeling }\end{array}$ & $\begin{array}{l}175 \% \times \text { rata-rata } \\
\text { premi penyadap }\end{array}$ \\
\hline Krani afdeling & - & $\begin{array}{l}90 \% \times \text { rata-rata premi } \\
\text { penyadap yang } \\
\text { diadministrasikan }\end{array}$ & - \\
\hline Krani lateks & $\begin{array}{l}125 \% \text { x rata-rata } \\
\text { premi penyadap }\end{array}$ & - & - \\
\hline Pembantu krani & - & $\begin{array}{l}125 \% \text { x rata-rata } \\
\text { premi penyadap yang } \\
\text { diadministrasikan }\end{array}$ & - \\
\hline Pekerja TPH & $\begin{array}{l}75 \% \text { x rata-rata premi } \\
\text { penyadap yang } \\
\text { dilayani }\end{array}$ & 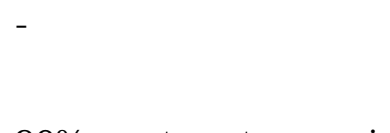 & $\begin{array}{l}(80-100) \% \mathrm{x} \\
\text { rata-rata premi } \\
\text { penyadap yang }\end{array}$ \\
\hline Penjaga afdeling & 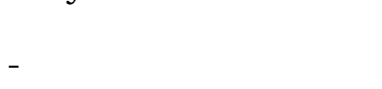 & $\begin{array}{l}90 \% \text { x rata-rata premi } \\
\text { penyadap afdeling }\end{array}$ & dilayani \\
\hline
\end{tabular}

Sumber : Perusahaan A, B, dan C (2010); diolah kembali Source : Companies A, B, and C(2010); data reprocessed 


\section{Fungsi Tap Kontrol terhadap Kualitas Sadapan}

Tap kontrol pada dasarnya bertugas dalam melakukan monitoring dan verifikasi penyadapan. Kegiatan monitoring dan verifikasi penyadapan dilakukan dengan mengacu pada norma yang tertuang dalam standar operasional prosedur (SOP) penyadapan. Hasil verifikasi sadap yang dilakukan kemudian menjadi dasar pertimbangan bagi afdeling, khususnya asisten dan mandor sadap untuk menentukan kelas dari masing-masing penyadap yang dibawahinya. Kelas penyadap tersebut selanjutnya akan menentukan besaran premi kualitas dan kuantitas yang akan didapat oleh penyadap.

Perusahaan A dan B menyadari bahwa penerapan TAP kontrol sudah jarang dilakukan secara konsisten dan berkesinambungan. Norma-norma sadap semakin diabaikan demi mencapai tingkat produktivitas yang ditargetkan perusahaan (Siagian, 2011). Secara umum fungsi tap kontrol di Perusahaan A dan B dijalankan oleh unit afdeling masing-masing di dalam kebun, yaitu oleh mandor/pengawas panen di bawah pengawasan dan persetujuan asisten. Sekalipun berada di luar unit afdeling, fungsi TAP kontrol seringkali didominasi oleh peran mandor dan asisten afdeling. Sementara pada Perusahaan C, fungsi TAP kontrol berdiri sendiri di luar struktur afdeling dan memiliki peluang jenjang karir sebagaimana seorang asisten. Dalam posisi seperti ini fungsi TAP kontrol dianggap berjalan dengan baik.

Sistem premi pekerja lain yang berkaitan dengan operasional panen sebagaimana telah diuraikan sebelumnya menyatakan bahwa penentuan besarnya nilai premi yang didapat oleh seorang mandor dan TAP kontrol dipengaruhi oleh besarnya nilai premi yang diterima oleh penyadap ataupun mandor yang dibawahinya. Lain halnya dengan mandor, pemberian premi kepada TAP kontrol seharusnya tidak dihitung berdasarkan ratarata jumlah premi penyadap ataupun mandor yang dibawahinya. Ketiadaan sistem kontrol yang independen seperti terjadi pada perusahaan A dan B membawa dampak pada penilaian kualitas sadapan yang kurang objektif. Sistem penilaian kelas penyadap yang diberikan kepada mandor dan asisten terhadap para penyadap membawa kecenderungan kepada penyeragaman kelas, tanpa memperhatikan kriteria kualitas sadapan yang ada.

Sebaiknya organisasi monitoring /verifikasi penyadapan berada di luar struktur afdeling dan memiliki peluang karir yang sama hingga ke level pimpinan baik di tingkat kebun maupun perusahaan. Sebagaimana berlaku pada Perusahaan C, peran TAP kontrol diatur bertingkat dari level

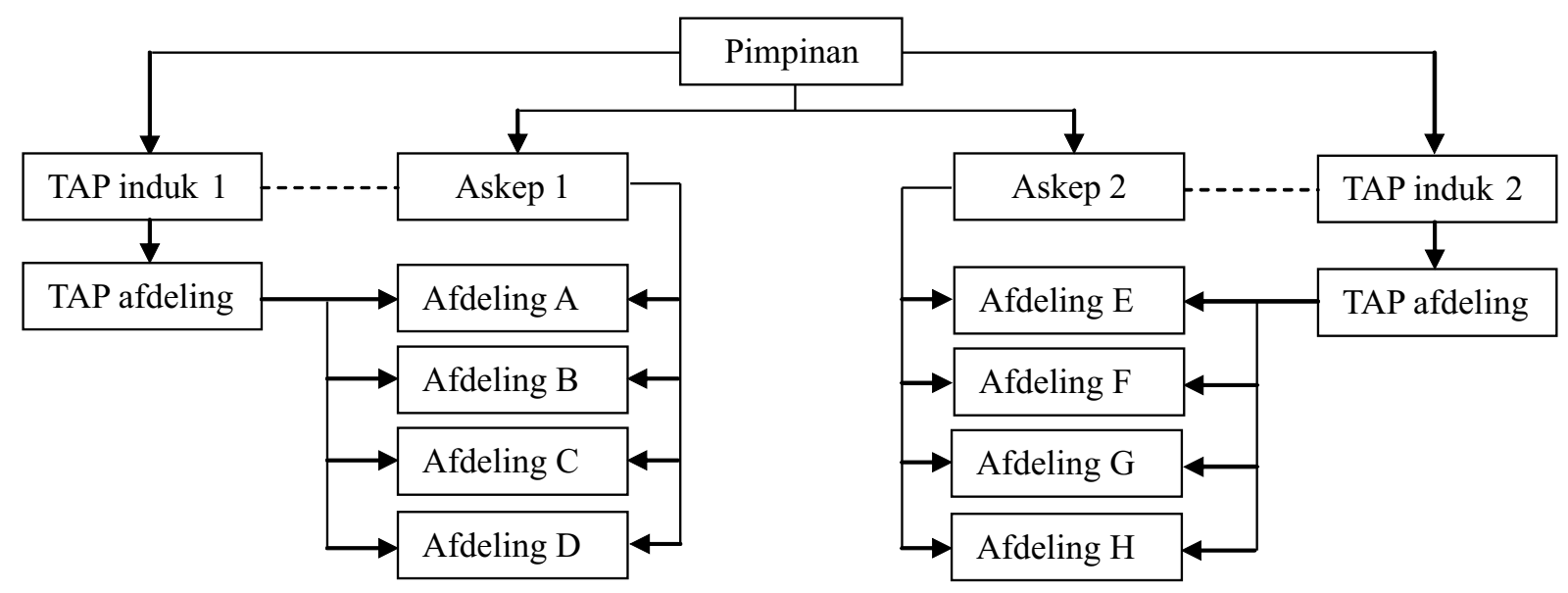

Gambar 2. Hierarki organisasi kebun ideal

Figure 2. Organization hierarchi of ideal plantation

Keeterangan : TAP kontrol induk berada sejajar dengan askep di bawah manager dan bekerjasama melakukan monitoring dan verifikasi penyadapan

Remaks : Primary TAP control is in line to the assistant manager under the manager and work together to monitor and verify tapping 
kebun hingga afdeling. Posisinya secara hierarki organisasi berada langsung di bawah kendali pimpinan kebun (manager), berkoordinasi dengan assisten manager (askep) dalam melakukan perbaikan kinerja di lapangan. Dengan struktur seperti ini fungsi TAP kontrol menjadi lebih objektif dalam melakukan monitoring dan verifikasi penyadapan di afdeling. Gambar 2 memperlihatkan struktur organisasi yang ideal dalam sebuah kebun.

\section{Kualitas Sadap dan Kelas Penyadap}

Berdasarkan hasil pengamatan lapangan di Perusahaan A dan B, penyadapan pada panel B0-1 yang baru dibuka sadap maupun yang telah disadap selama 2 tahun menunjukkan hasil sadapan yang sesuai dengan norma sadap. Hal ini terlihat pada tingkat kesalahan penyadap yang rendah yaitu $\leq 14$ nilai kesalahan, sehingga penyadap pada panel BO-1 dikategorikan ke dalam predikat kelas A. Namun untuk penyadapan pada panel B0-2, penyadap mulai banyak melakukan kesalahan sehingga masuk ke dalam kategori predikat kelas penyadap C. Kesalahan yang umum dilakukan pada panel B0-2 antara lain penyadapan yang banyak melukai kayu, konsumsi kulit yang terlalu boros, kedalaman sadap belum sesuai norma, dan sudut sadapan yang lebih besar dari standar yang telah ditentukan.
Persentase kesalahan terbanyak terjadi pada penyadapan yang terlalu dalam hingga melukai kulit, sehingga dapat menimbulkan kerusakan (benjol-benjol) pada kulit pulihan yang akan terbentuk beberapa tahun kemudian (Gambar 3.a dan 4.a).

Hasil pengamatan di Perusahaan A memperlihatkan bahwa minimnya penerapan standar norma penyadapan umumnya terjadi pada penyadapan panel atas (HO), meski tidak jarang ditemukan penyadapan pada panel bawah (BO) yang tidak memenuhi standar norma penyadapan yang ada. Hal ini dimaklumi mengingat tingkat kesulitan penyadapan pada panel atas relatif lebih tinggi dibanding penyadapan pada panel bawah. Gambar 3b dan 3c memperlihatkan salah satu contoh hasil sadap di Perusahaan A pada penyadap kelas A. Gambar tersebut memperlihatkan kualitas penyadapan pada tahun tanam 1997 di panel atas (H0-1/BI-1). Jika diperhatikan, Gambar $4 \mathrm{~b}$ dan 4c memperlihatkan pemakaian kulit yang berlebihan, dimana penyadapan yang dilakukan sudah mencapai hingga cabang batang. Selain itu terdapat banyak bekas luka kayu dan irisan sadap yang terlalu panjang melewati garis sandaran depan dengan kemiringan sudut sadap yang relatif curam (>45 derajat).
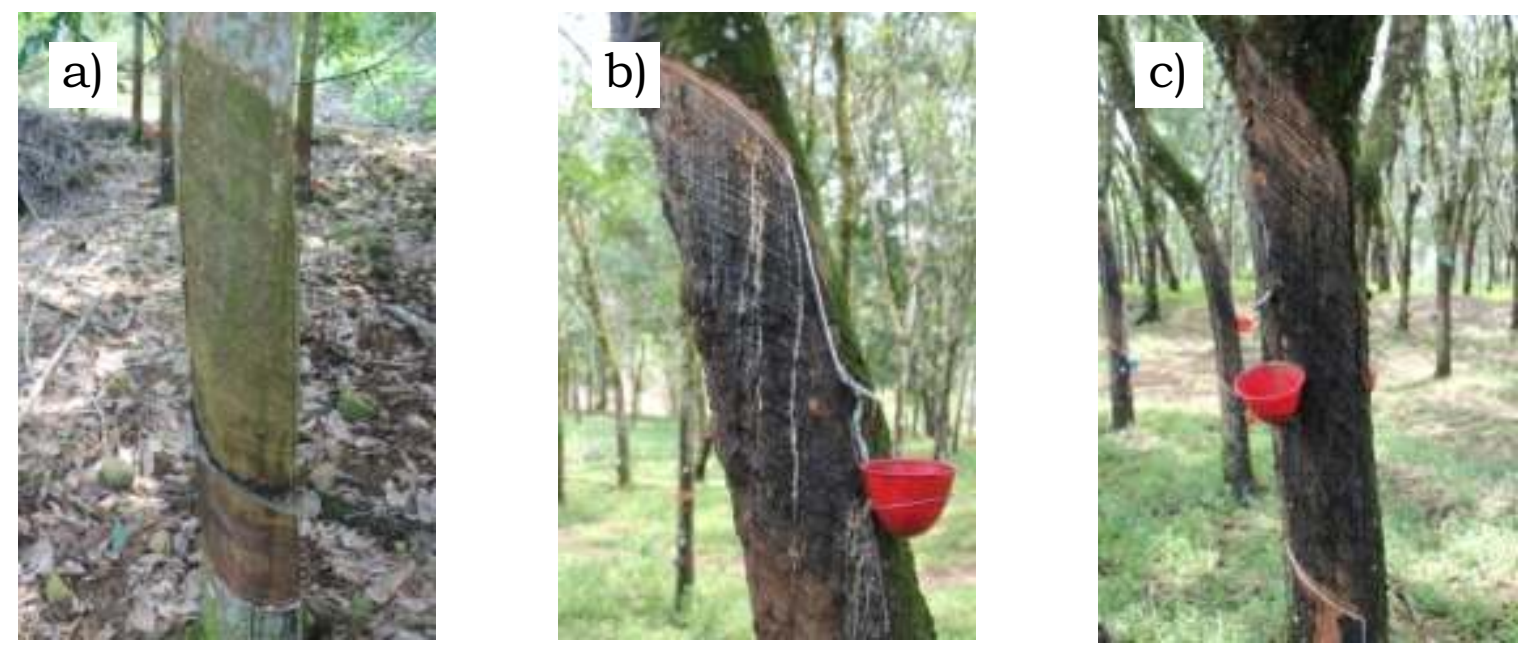

Gambar 3. a) Kualitas sadap panel bawah; b) dan c) kualitas sadap panel atas Figure 3. a) Tapping quality of downward panel; b) and c) tapping quality ofupward panel 
Pengamatan lain di perusahaan B pada panel HO juga menunjukkan hal yang sama dimana kelas penyadap pada panel tersebut termasuk kelas D. Kesalahan yang umum dilakukan pada panel ini antara lain penyadapan melukai kayu, pemakaian kulit boros, penyadapan terlalu dalam, dan sudut sadapan yang lebih besar dari standar yang telah ditentukan (Gambar 3.b). Biasanya fungsi kualitas penyadapan akibat penyeragaman kelas penyadap secara tidak langsung berakibat pada hilangnya motivasi penyadap untuk melakukan penyadapan dengan baik sesuai dengan norma yang ditetapkan. Kegiatan penyadapan cenderung hanya berorientasi pada volume produksi yang besar tanpa memperhatikan pemakaian kulit dan kriteria kualitas sadap lainnya. Dengan kata lain, motivasi penyadap untuk melakukan penyadapan dengan baik menjadi hilang akibat ketiadaan insentif terhadap kualitas sadap. Peran TAP kontrol yang cenderung masih berada di bawah kendali afdeling dianggap menjadi salah satu faktor penyebab fungsi monitoring dan verifikasi sadap tidak berjalan objektif sehingga kelas penyadap tidak lagi mampu merepresentasikan kualitas sadapan di lapangan.

Di ketiga perusahaan yang diamati, tingkat kesesuaian kelas penyadap dan kualitas sadapan memiliki keragaan yang berbeda-beda (Tabel 16). Pada posisi bidang sadap B0-1, ketiga perusahaan menunjukkan performa yang baik dalam menjaga dan memberikan penilaian kualitas sadapan dengan tingkat kesesuaian kelas penyadap dan kualitas sadapan yang mencapai angka 100\%. Namun setelah mencapai posisi bidang panel BO-2, Perusahaan A dan B menunjukkan tingkat kesesuaian yang rendah dalam memberikan penilaian kualitas sadapan, dimana masingmasing perusahaan memiliki tingkat kesesuaian sebesar 65\% dan 55\%. Demikian halnya terjadi pada posisi bidang sadap HO/BI, dimana tingkat kesesuaian kelas penyadap dan kualitas sadapan hanya mencapai masing-masing $35 \%$ dan $25 \%$. Dari ketiga perusahaan yang diamati, terlihat bahwa kesesuaian kelas penyadap dan kualitas sadapan secara konsisten diterapkan oleh Perusahaan C, dimana tingkat kesesuaian kelas penyadap dan kualitas sadapan pada masing-masing posisi bidang panel yang diamati mencapai angka $100 \%$. Hal ini menunjukkan bahwa peran TAP kontrol dalam memberikan penilaian kualitas sadapan berjalan dengan baik. Hal ini diduga didukung oleh peran organisasi TAP kontrol yang berdiri di luar struktur afdeling dan secara hierarki berada langsung di bawah komando manajer kebun. Posisi seperti ini diyakini mampu memperkecil pengaruh afdeling terhadap TAP kontrol dalam memberikan penilaian kualitas sadapan kepada penyadapnya.
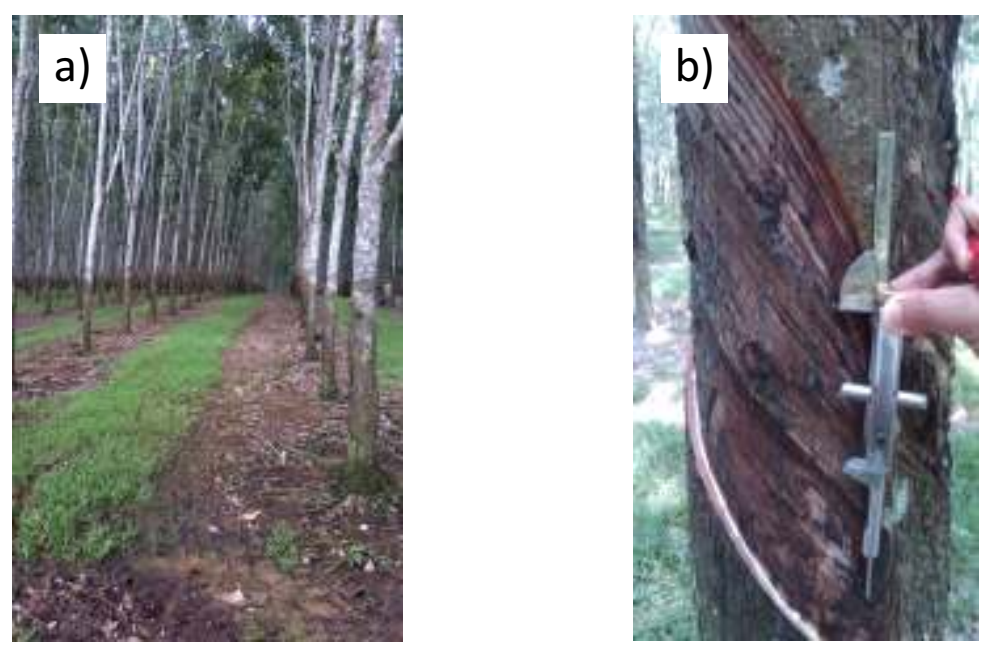

Gambar 4. a) Kerusakan kulit pulihan akibat penyadapan melukai kayu pada panel. B0-2; b) Sudut sadapan lebih besar dari standar pada panel atas

Figure 4. a) Damaged bark renewal due to tapping error on panel BO-2; b) Tapping angle on upward panel is bigger than standard 
Tabel 16. Kesesuaian kelas penyadap dan kualitas sadapan pada bidang sadap yang berbeda di masing-masing perusahaan

Table 16. Suitability of tapper class and tapping quality on different tapping panels in each company

\begin{tabular}{cccc}
\hline \multirow{2}{*}{$\begin{array}{c}\text { Perusahaan } \\
\text { Company }\end{array}$} & \multicolumn{3}{c}{$\begin{array}{c}\text { Kesesuaian kelas penyadap dan kualitas sadapan menurut bidang } \\
\text { sadap Suitability of tapper class and tapping quality by tapping panel } \\
(\%)\end{array}$} \\
\cline { 2 - 4 } & B0-1 & B0-2 & HO/BI \\
\hline A & 100 & 65 & 35 \\
B & 100 & 55 & 25 \\
C & 100 & 100 & 100 \\
\hline
\end{tabular}

Sumber: Data primer

Source : Prime data

\section{Pendapatan Premi Penyadap}

Untuk melihat keragaan premi dalam kaitannya dengan kelas penyadap dilakukan wawancara dan analisis data premi penyadap dalam sembilan bulan terakhir (Januari-September, 2012) di Perusahaan A. Berdasarkan data dan hasil wawancara yang dilakukan pada beberapa penyadap di Perusahaan A secara umum rata-rata pendapatan penyadap dari premi adalah sebesar $\mathrm{Rp}$ 404.217. Total tersebut mencakup empat jenis premi, yaitu premi prestasi, premi kerajinan, premi khusus, dan premi hari libur. Premi prestasi hari biasa, menyumbang sebesar $41 \%$ dari total pendapatan premi tersebut, sementara lainnya mencakup premi sadap hari minggu/libur (17\%), premi kerajinan $(19 \%)$, dan premi khusus (23\%). Gambar 5 memperlihatkan proporsi pendapatan premi penyadap (Januari-September, 2012).

Pendapatan premi rata-rata tertinggi selama Januari - September 2012 mencapai Rp. 469.849,--, sementara pendapatan premi rata-rata terrendah hanya sebesar $\mathrm{Rp}$ 306.685,-. Meski pendapatan rata-rata terbesar berasal dari premi prestasi, yaitu berada pada kisaran Rp. 108.000,- hingga Rp. 234.000,-, namun nilai tersebut belum mampu mendorong penyadap untuk melakukan penyadapan dengan baik. Besarnya nominal tersebut tergantung pada prestasi produksi yang dicapai penyadap. Sistem premi harus diatur sedemikian rupa sehingga mampu mendorong penyadap untuk menjaga kualitas sadapannya sesuai

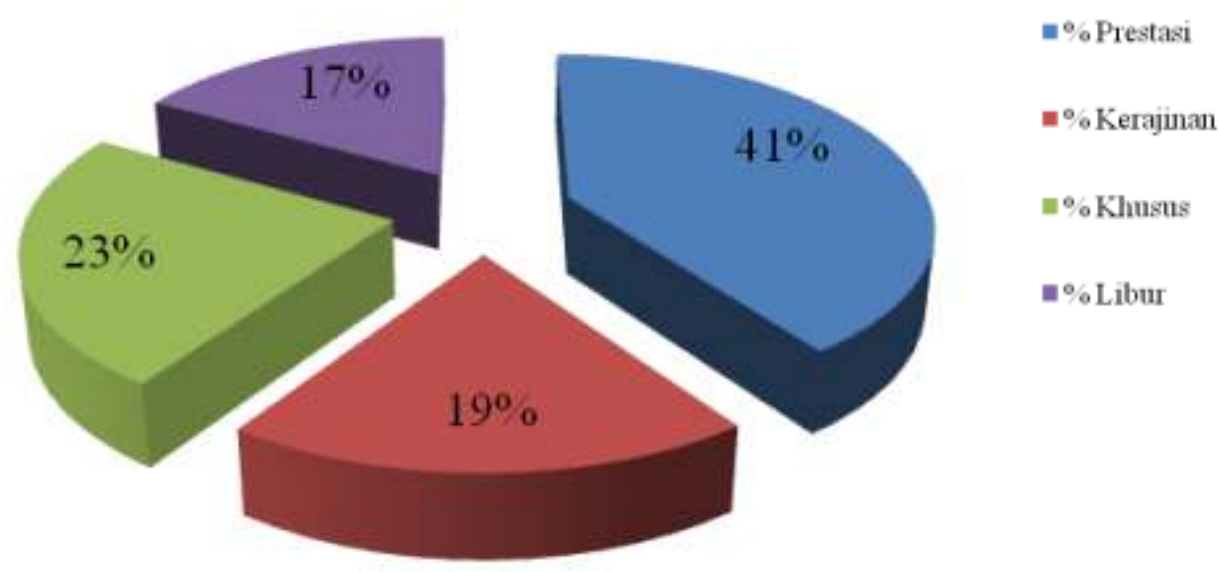

Gambar 5. Komposisi pendapatan premi penyadap Perusahaan A, (tahun 2012) Figure 5. Composition of tappers premium income in Company A, (year 2012) 
dengan norma yang telah ditetapkan perusahaan, untuk itu tarif premi yang melekat langsung pada predikat kelas penyadap dan kualitas sadapan (premi kualitas) harus ditentukan lebih tinggi dari jenis premi yang hanya berorientasi pada kuantitas hasil sadapan (premi kuantitas). Salah satu contoh mengenai pendapatan rata-rata premi penyadap disajikan pada Tabel 17.

Jika dibandingkan dengan pendapatan premi pemanen sawit maka pendapatan premi penyadap relatif lebih rendah. Meski memiliki rata-rata pendapatan premi yang tidak berbeda signifikan, yaitu sebesar Rp 496.010,/bulan namun pada beberapa pemanen sawit pendapatan premi dapat mencapai rata-rata $\mathrm{Rp} 816.779,-$ hingga $\mathrm{Rp}$ 1.244.931,-. Kondisi ini seringkali menjadi pemicu kecemburuan yang menyangkut pendapatan karyawan pada suatu perusahaan yang mengelola dua komoditas ini secara bersamaan. Kecenderungan yang ada dari ketiga perusahaan yang diamati adalah ketika seorang penyadap melakukan kesalahan atau tidak mampu menjalankan tugas penyadapan dengan baik maka penyadap tersebut dipindahkan untuk menjadi pemanen sawit. Kondisi seperti ini didorong akibat keterbatasan jumlah tenaga kerja pada umumnya dan sulitnya mencari tenaga penyadap yang terampil akibat preferensi tenaga kerja yang rendah terhadap pekerjaan menyadap (Siregar et al., 2009). Dalam kondisi seperti ini dikhawatirkan bahwa fenomena yang terjadi terkait dengan ketidaksesuaian kelas penyadap dan kualitas sadapan adalah akibat dari timbulnya kesengajaan dari seorang penyadap yang melakukan pekerjaannya secara asal agar dapat dimutasi menjadi pemanen sawit, sementara kebun tidak memiliki keberanian untuk melepas tenaga kerja akibat sulitnya mencari tenaga kerja. Tabel 18 memperlihatkan keragaan pendapatan pemanen sawit dalam sembilan bulan (Januari - September) tahun 2012.

Tabel 17. Pendapatan premi penyadap Perusahaan A

Table 17. Tappers premium income in Company A

\begin{tabular}{|c|c|c|c|c|c|c|}
\hline \multirow[t]{2}{*}{$\begin{array}{l}\text { Tahun tanam } \\
\text { Planting year }\end{array}$} & \multirow{2}{*}{$\begin{array}{l}\text { Bidang } \\
\text { sadap } \\
\text { Tapping } \\
\text { panel }\end{array}$} & \multicolumn{5}{|c|}{$\begin{array}{l}\text { Pendapatan premi } \\
\text { (Rp/bulan) } \\
\text { Premiums income } \\
\text { (Rp/month) }\end{array}$} \\
\hline & & $\begin{array}{c}\text { Prestasi } \\
\text { Achievement }\end{array}$ & $\begin{array}{l}\text { Kerajinan } \\
\text { Discipline }\end{array}$ & $\begin{array}{l}\text { Khusus } \\
\text { Special }\end{array}$ & $\begin{array}{l}\text { Libur } \\
\text { Holiday }\end{array}$ & Total \\
\hline 2006 & B0-1 & 185.147 & 82.749 & 37.362 & 76.473 & 381.731 \\
\hline 2005 & B0-1 & 179.040 & 76.944 & 84.846 & 59.573 & 400.403 \\
\hline 2005 & B0-1 & 163.800 & 77.167 & 84.846 & 92.182 & 417.995 \\
\hline 2005 & B0-1 & 156.640 & 76.500 & 84.846 & 74.378 & 392.363 \\
\hline 2003 & B0-1 & 185.827 & 61.438 & 65.112 & 82.182 & 394.558 \\
\hline 2002 & B0-2 & 228.380 & 75.722 & 81.308 & 77.256 & 462.666 \\
\hline 2002 & B0-2 & 234.057 & 78.500 & 82.192 & 75.100 & 469.849 \\
\hline 2002 & B0-2 & 215.860 & 77.444 & 79.541 & 70.789 & 443.634 \\
\hline 1998 & $\mathrm{HO} / \mathrm{BI}$ & 122.893 & 75.833 & 137.867 & 53.167 & 389.760 \\
\hline 1998 & $\mathrm{HO} / \mathrm{BI}$ & 108.080 & 74.111 & 128.147 & 48.067 & 358.405 \\
\hline 1998 & HO/BI & 54.012 & 76.556 & 138.751 & 37.367 & 306.685 \\
\hline 1997 & HO/BI & 180.509 & 82.367 & 77.548 & 92.133 & 432.557 \\
\hline \multicolumn{2}{|c|}{$\begin{array}{l}\text { Rata-rata } \\
\text { Average }\end{array}$} & 167.854 & 76.278 & 90.197 & 69.889 & 404.217 \\
\hline
\end{tabular}

Sumber: Perusahaan A (2012); diolah kembali

Source: Company A (2012); data reprocessed 
Tabel 18. Keragaan premi pemanen sawit Perusahaan A pada Januari-September 2012 Table 18. Variability of palm oil harvester in Company A on Januari-September 2012

\begin{tabular}{|c|c|c|c|c|c|c|c|c|c|c|}
\hline \multirow{2}{*}{$\begin{array}{l}\text { No. } \\
\text { hanca. } \\
\text { Task } \\
\text { number }\end{array}$} & \multicolumn{9}{|c|}{$\begin{array}{l}\text { Pendapatan premi (Rp/bulan) } \\
\text { Premium income (Rp/month) }\end{array}$} & \multirow{2}{*}{$\begin{array}{c}\text { Rata- } \\
\text { rata } \\
\text { Average }\end{array}$} \\
\hline & Januari & Februari & Maret & April & Mei & Juni & Juli & Agustus & September & \\
\hline 1 & 446.983 & 417.818 & 635.369 & 860.993 & 982.036 & 1.227 .268 & 819.479 & 706.712 & 646.067 & 749.192 \\
\hline 2 . & 417.900 & 453.163 & 470.260 & 762.946 & 975.669 & 1.005 .563 & 872.515 & 819.128 & 685.928 & 718.119 \\
\hline 3. & 147.703 & 300.133 & 329.353 & 414.904 & 369.608 & 731.416 & 434.417 & 427.057 & 433.980 & 398.730 \\
\hline 4. & 419.432 & 527.486 & 789.492 & 888.467 & 1.125 .220 & 1.244 .931 & 584.553 & 872.039 & 899.388 & 816.779 \\
\hline 5 . & 334.042 & 535.135 & 639.802 & 591.109 & 861.158 & 1.196 .520 & 744.324 & 957.210 & 806.190 & 740.610 \\
\hline 6. & 273.923 & 169.579 & 320.357 & 314.582 & 352.659 & 534.522 & 374.960 & 660.872 & 462.018 & 384.830 \\
\hline 7 . & 181.792 & 158.058 & 154.459 & 230.667 & 290.913 & 383.567 & 281.703 & 396.639 & 342.735 & 268.948 \\
\hline 8. & 188.924 & 219.686 & 184.709 & 233.517 & 374.977 & 496.766 & 493.904 & 477.700 & 428.265 & 344.272 \\
\hline 9. & 237.130 & 278.424 & 158.944 & 386.272 & 446.950 & 658.660 & 501.669 & 393.526 & 456.464 & 390.893 \\
\hline 10 . & 278.122 & 254.651 & 432.965 & 474.259 & 538.308 & 566.138 & 565.712 & 556.393 & 514.625 & 464.575 \\
\hline 11. & 392.125 & 132.160 & 132.642 & 241.914 & 289.265 & 408.597 & 280.187 & 439.726 & 423.912 & 304.503 \\
\hline 12 . & 263.742 & 217.725 & 201.237 & 479.985 & 397.831 & 570.697 & 449.117 & 345.447 & 403.703 & 369.943 \\
\hline 13. & 344.557 & 198.335 & 556.039 & 525.117 & 605.725 & 887.616 & 725.974 & 635.634 & 499.164 & 553.129 \\
\hline 14 . & 271.577 & 349.903 & 448.090 & 683.702 & 569.718 & 723.711 & 701.743 & 647.391 & 524.811 & 546.738 \\
\hline 15. & 383.577 & 345.472 & 535.632 & 815.980 & 756.795 & 1.047 .879 & 671.090 & 588.300 & 593.256 & 637.553 \\
\hline 16. & 195.137 & 178.868 & 239.058 & 304.836 & 243.636 & 596.007 & 477.590 & 400.788 & 394.787 & 336.745 \\
\hline 17. & 249.477 & 263.350 & 338.379 & 428.604 & 351.587 & 590.421 & 435.439 & 581.912 & 420.391 & 406.618 \\
\hline $\begin{array}{l}\text { Rata- } \\
\text { rata } \\
\text { Average }\end{array}$ & 295.655 & 294.114 & 386.282 & 508.109 & 560.709 & 757.075 & 553.787 & 582.734 & 525.628 & 496.010 \\
\hline
\end{tabular}

Sumber : Perusahaan A (2012); diolah kembali

Source : Company A (2012); data reprocessed

\section{KESIMPULAN DAN SARAN}

Penyadapan merupakan faktor penting dalam kegiatan budidaya tanaman karet. Besar kecilnya keuntungan sangat tergantung dari faktor kualitas dan kuantitas hasil penyadapan. Di sebuah perusahaan perkebunan karet, selain faktor teknis budidaya, faktor nonteknis dalam manajemen pengelolaan kebun juga memiliki pengaruh besar, salah satunya adalah sistem premi. Secara umum jenis premi penyadapan di perkebunan karet meliputi 1) premi hari biasa (premi prestasi, premi kerajinan, dan premi khusus), premi hari libur, dan premi sadap bebas. Untuk mendukung dan menjaga penyadapan memperoleh kualitas dan kuantitas yang baik maka diberikan premi kepada pekerja lain seperti premi mandor besar, mandor sadap, TAP kontrol induk, TAP kontrol afdeling, koordinator produksi, krani afdeling, pembantu krani, pekerja TPH, dan penjaga afdeling. Sebagai instrumen dari upah kerja, sistem premi di beberapa kebun secara umum masih belum mampu mengakomodir kepentingan penyadap untuk melakukan penyadapan dengan baik sesuai norma. Pengaruh tarif premi terhadap perbedaan kelas penyadap masih dianggap kecil sehingga motivasi penyadap untuk mendapatkan kelas terbaik menjadi rendah. Predikat kelas yang melekat pada penyadap belum mampu menjamin representasi kualitas sadap di lapangan. Lemahnya faktor pengawasan juga merupakan salah satu sebab kegiatan penyadapan belum memberikan hasil yang optimal.

Beberapan saran yang dianggap penting dalam penelitian ini adalah :

1. Estimasi/target produksi seyogianya ditetapkan secara realistis berdasarkan kondisi tanaman dengan memperhatikan jenis klon, umur, kesehatan, jumlah pokok disadap, sistem sadap, posisi panel, topografi lahan dan faktor lain yang berkaitan dengan musim. Target dan basis yang terlalu tinggi cenderung akan membawa beban psikologis yang berat bagi penyadap sehingga 
mendorong penyadap melakukan eksploitasi tanaman secara berlebihan (di luar standar) karena hanya berorientasi pada volume produksi.

2. Penerapan jenis premi yang berhubungan dengan kelas penyadap harus didukung dengan nilai tarif yang berbeda signifikan antara penyadap terbaik dan terburuk sehingga motivasi penyadap untuk menghasilkan kualitas sadap yang baik semakin meningkat. Tarif premi harus sebanding dengan tingkat kesulitan penyadapan, baik terkait dengan topografi, luas lahan maupun ketinggian bidang sadap. Pada tingkat kesulitan penyadapan yang lebih tinggi (topografi berbukit, lahan luas, atau posisi panel yang tinggi) tarif premi sebaiknya diatur lebih besar dari kondisi normal.

3. Perusahaan harus mampu memilah jenis premi mana yang berdampak langsung pada produksi dan kualitas sadapan serta mana yang hanya sebatas pada atribut kebersihan dan kedisiplinan penyadap dalam pengelolaan hancanya. Diantara premi penyadap yang menjadi prioritas adalah premi prestasi (premi kualitas dan kuantitas) yang melekat langsung pada kualitas sadapan. Sementara jenis premi kerajinan yang paling utama memberikan manfaat bagi perusahaan adalah 1) premi kehadiran, 2) premi kutip lump, 3) premi pungut tetesan sore, dan 4) premi kutip scrap.

4. Untuk menjaga kualitas sadap pada tanaman yang baru dibuka sadap maka sebaiknya digunakan penyadap dengan predikat kelas A. Tarif premi kualitas yang diberlakukan harus dapat diatur lebih besar dari tarif premi kualitas pada kondisi normal. Basis tugas sebagaimana diberlakukan pada sadap biasa sebaiknya ditiadakan untuk mencegah adanya beban psikologis penyadap untuk mencapai hasil sadap sesuai basis tugas tersebut. Ketentuan premi ini sebaiknya diberikan selama satu tahun pada tahun sadap pertama.

5. Penyadapan pada hari libur sebaiknya tidak dilakukan pada tahun pertama penyadapan, sebab kualitas sadap pada tahun pertama akan sangat menentukan potensi hasil pada tahun-tahun berikutnya. Pertimbangan predikat kelas penyadap terhadap penentuan tarif premi diperlukan untuk tetap menjaga motivasi penyadap melakukan penyadapan dengan baik. Peran pengawasan juga perlu diperhatikan untuk mengantisipasi kemungkinan penyadap mengalihkan produksi hari sebelumnya ke hari sadap libur (terutama produksi lump).

6. Pemberian premi pekerja lain yang berkaitan dengan operasional panen harus menekankan pada kontribusinya terhadap kegiatan penyadapan, sehingga pemberian premi tidak memberikan kesan inefisiensi bagi perusahaan. Diantara sejumlah jenis premi pekerja lain yang berkaitan dengan operasional panen, beberapa jenis premi yang dianggap penting adalah premi mandor besar, premi mandor sadap, premi TAP kontrol, premi krani afdeling, premi pembantu krani, premi pekerja TPH, dan premi penjaga afdeling.

7. Pemberian premi kepada TAP kontrol sebaiknya tidak dihitung berdasarkan rata-rata premi penyadap ataupun mandor, akan tetapi berdasarkan prestasi dalam melakukan tugasnya. Seyogianya organisasi TAP kontrol berada di luar struktur afdeling dan memiliki peluang karir yang sama hingga ke level pimpinan baik di tingkat kebun maupun perusahaan. Peran TAP kontrol diatur bertingkat dari level kebun hingga afdeling. Posisinya secara hierarki organisasi berada langsung dibawah kendali pimpinan kebun (manager), berkoordinasi dengan assisten manager (askep) dalam melakukan perbaikan kinerja di lapangan. Dengan struktur seperti ini fungsi TAP kontrol menjadi lebih objektif dalam melakukan monitoring dan verifikasi penyadapan di afdeling.

8. Sistem premi harus diatur sedemikian rupa sehingga mampu mendorong penyadap untuk menjaga kualitas sadapannya sesuai dengan norma yang telah ditetapkan perusahaan, untuk itu tarif premi yang melekat langsung pada predikat kelas penyadap dan kualitas sadapan (premi kualitas) harus ditentukan lebih tinggi dari jenis premi yang hanya berorientasi pada kuantitas hasil sadapan (premi kuantitas). 
9. Diperlukan inisiasi sistem competitive reward tahunan bagi penyadap terbaik atas dasar kriteria kualitas sadap mereka di lapangan. Selain berdasarkan kualitas dan kuantitas hasil sadapan, kriteria penilaian penyadap terbaik harus mampu mengakomodir jenis-jenis premi yang terkait dengan atribut kebersihan dan kedisiplinan dalam pengelolaan hanca.

10. Ditengah keterbatasan jumlah penyadap terampil, bagi perusahaan perkebunan yang mengelola dua komoditas berbeda secara bersamaan maka tarif premi sebaiknya diatur sedemikian rupa sehingga bernilai kompetitif antara satu dengan lainnya. Hal ini dilakukan untuk mencegah kemungkinan timbulnya kecemburuan yang menyangkut pendapatan karyawan.

\section{UCAPAN TERIMA KASIH}

Ucapan terima kasih disampaikan kepada segenap pimpinan perusahaan perkebunan A, B, dan C beserta jajaran (manager, askep, asisten, mandor, dan penyadap) yang telah mendukung pelaksanaan kegiatan penelitian ini, serta kepada pihak yang tidak dapat kami sebutkan satu persatu.

\section{DAFTAR PUSTAKA}

Mahyuddin, Majdah, dan M. Zein. 2010. Elastisitas Permintaan Tenaga Kerja dan Kekakuan Upah Riil Sektoral di Sulawesi Selatan. J. Agro. Eko. 28(2): 113-132.

Nancy, C., C. Anwar, Junaedi dan S. Hendratno. 1997. Ketersediaan dan Kesejahteraan Tenaga Penyadap di Perkebunan Karet. J. Penel. Karet. 15(1), $23-41$.

Panjaitan, L. 1997. Kajian Efisiensi Penggunaan Tenaga Kerja Pada Perkebunan Karet. Makalah Evaluasi Hasil Penelitian. Disampaikan pada Pra Raker II di Pekanbaru, tanggal 17 - 18 Februari 1997. Medan : Pusat Penelitian Karet.
Perusahaan A. 2010. Pedoman Premi Perusahaan A. Dokumen Internal Perusahaan A. Perusahaan A, Sumatera Utara.

Perusahaan A. Evaluasi Sistem Eksploitasi Tanaman Karet di Kebun Lingkup Perusahaan A. Dokumen Internal Perusahaan A. Perusahaan A, Sumatera Utara.

Perusahaan B. 2010. Pedoman Premi Perusahaan B. Dokumen Internal Perusahaan B. Perusahaan B, Sumatera Selatan.

Perusahaan B. Rekomendasi Sistem Eksploitasi Tanaman Karet di Kebun Lingkup Perusahaan B. Dokumen Internal Perusahaan B. Perusahaan B, Sumatera Selatan.

Perusahaan C. 2010. Pedoman Premi Perusahaan C. Dokumen Internal Perusahaan C. Perusahaan C, Jawa Tengah.

Perusahaan C. Evaluasi Sistem Eksploitasi Untuk Meningkatkan Produktivitas Tanaman Karet di Kebun Lingkup Perusahaan C. Dokumen Internal Perusahaan C. Perusahaan C, Jawa Tengah.

Siagian, N. 2010. Penentuan Target Produksi Tanaman Karet Untuk Tahun Depan. Workshop Optimalisasi Produksi Melalui Teknik Eksploitasi Tanaman Karet. Medan, 4-7 Oktober. Balai Penelitian Sungei Putih.: halaman

Siagian, N dan T. H. S. Siregar. 2011. Pemeriksaan Kualitas Sadapan Untuk Mendukung Produktivitas yang Tinggi dan Berkelanjutan. Warta Perkaretan. 30 (1): $34-43$.

Siregar, T. H. S, I. Suhendry, dan Sumarmadji. 2009. Manajemen Sistem Eksploitasi Menghadapi Dinamika Harga Karet dan Biaya. Pertemuan Teknis Eksploitasi Tanaman Karet. Medan, .Pusat Penelitian Karet.: halaman 